\title{
Mercury-Free PVT Apparatus for Thermophysical Property Analyses of Hydrocarbon Reservoir Fluids
}

United States Department of Energy

Grant No. 01-90CE15454.0n?

\section{FINAL REPORT}

August 16, 1990 - July 31, 1992
Robbie M. Lansangar:

Principal Investigator
John S. Lievois

Principal Investigator

\section{DISCLAIMER}

This report was prepared as an account of work sponsored by an agency of the United States Government. Neither the United States Government nor any agency thereof, nor any of their employees, makes any warranty, express or implied, or assumes any legal liability or responsibility for the accuracy, completeness, or usefulness of any information, apparatus, product, or process disclosed, or represents that its use would not infringe privately owned rights. Reference herein to any specific commercial product, process, or service by trade name, trademark, manufacturer, or otherwise does not necessarily constitute or imply its endorsement, recomme United States Government or any agency thereof. The views mendation, or favoring by the United States do not necessarily state or reflect those of the United States Government or any agency thereof.

\author{
Ruska Instrument Corporation \\ 3601 Dunvale Road \\ Houston, TX 77063 \\ (713) 975-0547
}

August 31, 1992 


\section{TABLE OF CONTENTS}

LIST OF FIGIJRES $\ldots \ldots \ldots \ldots \ldots \ldots \ldots \ldots \ldots \ldots \ldots \ldots \ldots$ ii

LIST OF TABLES $\ldots \ldots \ldots \ldots \ldots \ldots \ldots \ldots \ldots \ldots \ldots \ldots \ldots \ldots \ldots$ iii

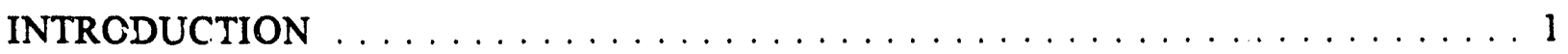

THE RUSKA 2370 MERCURY-FREE PVT SYSTEM OVERVIEW $\ldots \ldots \ldots \ldots \ldots 2$

2370 PERFORMANCE TESTING AND ENHANCEMENTS $\ldots \ldots \ldots \ldots \ldots \ldots$

Seal Material, Fluid Media, and Temperature Compatibility $\ldots \ldots \ldots \ldots \ldots \ldots 11$

Sample Drainage and Cleaning Procedures $\ldots \ldots \ldots \ldots \ldots \ldots \ldots, \ldots \ldots$

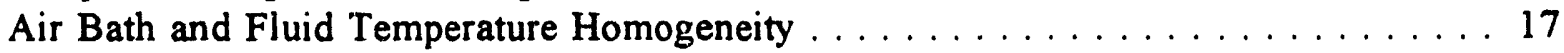

APPLICATIONS TESTING AND COMPARISON WITH A CONVENTIONAL MERCURY-

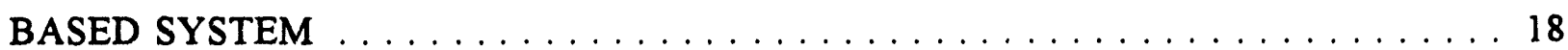

Density Measurements on Pure Propane . . . . . . . . . . . . . . . . . 19

Black Oil Tests - Constant Composition Expansion and Differential Liberation Tests . 24 Gas Condensate Tests - Constant Compositions Expansion and Liquid Dropout Measurements . . . . . . . . . . . . . . . . . . . . . . . . . 39

FUTURE PROJECTS $\ldots \ldots \ldots \ldots \ldots \ldots \ldots \ldots \ldots \ldots \ldots \ldots \ldots$

CONCLUDING REMARKS $\ldots \ldots \ldots \ldots \ldots \ldots \ldots \ldots \ldots \ldots \ldots$

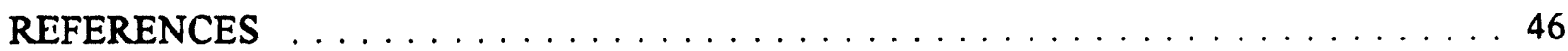




\section{LIST OF FIGURES}

Figure 1. Ruska Model $2370-601$ PVT System $\ldots \ldots \ldots \ldots \ldots \ldots$

Figure 2. Ruska Model 2370-601 PVT System - Dual Cell Arrangement . . . . . . . . 4

Figure 3. Cross-Sectional View of a Parker Polypak Seal $\ldots \ldots \ldots \ldots \ldots \ldots$

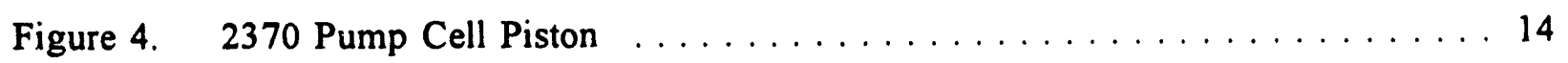

Figure 5. Pressure-Density Relation for Propane at $116.4^{\circ} \mathrm{F} \ldots \ldots \ldots \ldots$

Figure 6. Pressure-Relative Volume Relation for Black Oil Mixture at $145^{\circ} \mathrm{F} \ldots \ldots$

Figure 7. Y-Function Curve for Relative Total Volume Data . . . . . . . . . . 26

Figure 8. Differential Liberation Relative Total and Relative Liquid Volume Data . . 27

Figure 9. Differential Liberation Solution/Gas Oil Ratio $\ldots \ldots \ldots \ldots \ldots$

Figure 10. Liberated Gas Gravity Data . . . . . . . . . . . . . . . . 29

Figure 11. Differential Liberation Gas Formation Volume Factor . . . . . . . . . . 30

Figure 12. Gas Compressibility Factor $\ldots \ldots \ldots \ldots \ldots \ldots \ldots \ldots \ldots \ldots \ldots$

Figure 13. Pressure-Relative Volume Data Comparison Between 2370 and Mercury-Based

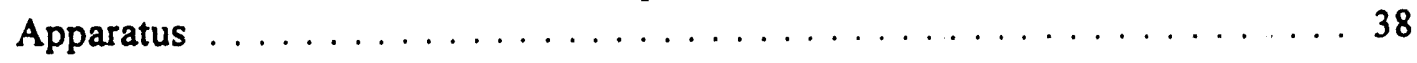

Figure 14. Relative Total Volume and Liquid Dropout Curve for Retrograde Condensate

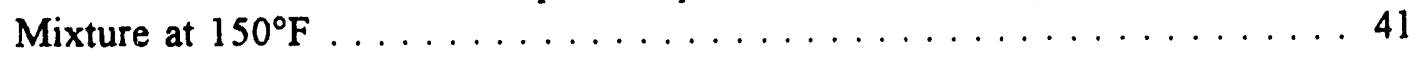

Figure 15. Comparison of 2370 and Mercury-Based Data on a Retrograde Coridensate System ............................4 43 


\section{LIST OF TABLES}

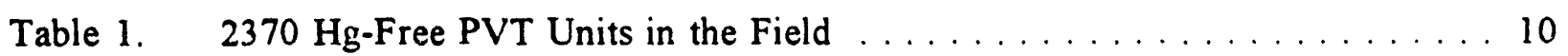

Table 2. Seal Materials for the Pump Cell Piston $\ldots \ldots \ldots \ldots \ldots \ldots \ldots \ldots$

Table 3. Parker Polypak Seal Material and Fluid Compatibility Table . . . . . . . 15

Table 4. Seal Material versus Temperature Compatibility Table $\ldots \ldots \ldots \ldots$

Table 5. Fluid Temperature Profile in the Pump Cell $\ldots \ldots \ldots \ldots \ldots \ldots$

Table 6. Comparison of Measured and EOS-Predicted Specific Volume at a

Subcritical Isotherm of $116.4^{\circ} \mathrm{F}$ for Propane . . . . . . . . . . 21

Table 7. Comparison of Measured and Literature Specific Volume at a Subcritical Isotherm of $116.4^{\circ} \mathrm{F}$ for Propane . . . . . . . . . . . . . . . 22

Table 8. Sensitivity and Error Analysis of the Data Point with Maximum Absolute Average Deviation from the EOS-Predicted Value . . . . . . . . 23

Table 9. Mole Fraction Distribution of the Gas Mixture and Stock Tank Oil . . . . 32

Table 10. Physical Properties of the Stock Tank Oil and Gas Mixture . . . . . . . . 32

Table 11. Summary of PVT Data for the Black Oil Mixture . . . . . . . . . 33

Table 12. Average Single-Phase Compressibilities $\ldots \ldots \ldots \ldots \ldots \ldots$

Table 13. Pressure-Volume Relations of the Black Oil Mixture $\ldots \ldots \ldots \ldots \ldots$

Table 14. Differential Liberation Data $\ldots \ldots \ldots \ldots \ldots \ldots$

Table 15. Comparison of 2370 and Mercury-Based Results for a Black Oil System _. 37

Table 16. Pressure-Volume Relation and Liquid Dropout Data for the Retrograde Condensate Mixture . . . . . . . . . . . . . . . . . . . . . . . . . . 40

Table 17. Comparison of 2370 and Mercury-Based Results for a Retrograde Condensate System 


\section{INTRODUCTION}

Traditionally, the oil and gas industry has not devoted ample interest to the details regarding the thermophysical properties and compositions of the produced hydrocarbon fluids from subterranean reservoirs. The composition of a crude oil, for instance, is determined only up to the hexanes $\left(\mathrm{C}_{6}\right)$, the balance being lumped into a heptanes-plus $\left(\mathrm{C}_{7+}\right)$ fraction. The scantness of thermodynamic and physical property data has, in part, led to the design of surface production equipment and reservoir management strategies that were largely based on empirical correlations that were oftentimes applied outside their ranges. This scheme, however, was not only insufficient but rather risky considering the enormous capital investments required for oil and gas exploration and production.

The economic and strategic impact unleashed by the oil embargo in the late 70's have forced the industry to pay closer attention to reservoir management and downstream handling and processing facilities. Today production schemes and surface equipment undergo elaborate design, concurrent engineering analysis, and numerical modeling to optimize the quantity of hydrocarbons produced while minimizing the operating expenses and capital investment cost.

The design, analysis, and implementation of reservoir management strategies and production facilities require a thorough knowledge of the thermodynamic and physical properties of the insitu hydrocarbon fluids. Of particular importance is the phase behavior of the fluids at reservoir conditions and at different states of pressure and temperature that can be encountered during production, separation, and transmission. Typical reservoir fluid analyses of complex, multicomponent hydrocarbon mixtures include the volumetric properties, isothermal compressibility, thermal expansivity, equilibrium ratios, saturation pressure, viscosities, etc. These parameters are collectively referred to as PVT properties, an acronym for the primary state variables; pressure, volume, and temperature. The reservoir engineer incorporates this information together with the porous media description in performing material balance calculations. These calculations lead to the determination (estimation) of the initial hydrocarbon in-place, the future reservoir performance, the optimal production scheme, and the ultimate hydrocarbon recovery.

Equipment used to measure PVT properties of reservoir fluids have been in existence for over forty years. The key component of these instruments is the relatively inert liquid metal mercury $(\mathrm{Hg})$. The use of mercury allows the volume of the system to be varied in a confined cell which can then be subjected to high pressures and temperatures. It also provides mechanical agitation to achieve single-phase homogeneity or the rapid equilibration of coexisting phases.

The mercury-based PVT apparatus has been the dominant method of generating PVT data despite the known problems associated with the use of mercury. Most black oils, for instance, form a stable emulsion with mercury which makes the oil-mercury interface non-distinct. This phenomenon dictates the need to purge a small amount of mercury every so often. Perhaps every PVT laboratory operator has experienced an occasional spill caused by leaks or the simple mishandling of the substance. This in itself is the crux of the problem inherent with the use of mercury. It is almost impossible to handle mercury without allowing some vapor to escape in the atmosphere. Worse, occasional spills result in small amounts of mercury settling in the cracks and crevices on laboratory equipment and floor, thus, contaminating the air in the work 
place. The biological effects of mercury vapor inhalation are well documented. The cumulative effect to the operators can be toxic over a period of prolonged exposure.

About four years ago, Ruska Instrument Corporation embarked on a project to develop an apparatus designed to measure PVT properties that operates free of mercury. The result of this endeavor is the $2370 \mathrm{Hg}$-Free PVT system which has been in the market for the last three years. The 2370 has evolved from the prototype unit to its present configuration which is described briefly in the proceeding section of the report.

Any new product introduced in the market that seeks to supplant an existing modus operandi is subject to the burden of showing documented proof that it performs as good, if not better, than the conventional equipment. The 2370 system, although developed as a system-engineered apparatus based on existing technology, has not been exempt from this burden-of-proof. Namely, the performance of the apparatus under routine test conditions with real reservoir fluids. Perhaps a more demanding task is the delineation of the limits of its operating capabilities.

Ruska Instrument Corporation has taken on this challenge with the support of the U.S. Department of Energy in conjunction with the Federal Non-nuclear Energy Research and Development Act of 1974. This report summarizes the results of the performance and applications testing of the $2370 \mathrm{Hg}$-Free PVT system. The project has resulted in the characterization of the operating capabilities of the instrument under actual test conditions. New measurement protocols were also developed for the new apparatus.

Density measurements were conducted on a pure fluid. The results were compared against literature values and the prediction of an equation of state. Routine reservoir fluid analyses were conducted with a black oil and a retrograde condensate gas mixtures. Limited comparison of the results were performed based on the same tests performed on a conventional mercury-based PVT apparatus. The results of these tests are included in this report.

An indirect result of the testing is the redesign and addition of certain key components that has greatly enhanced the functionality and reliability of the apparatus. These are discussed in the following sections.

\section{SYSTEM OVERVIEW}

The $2370 \mathrm{Hg}$-Free PVT system is shown in Fig. 1 and a schematic of the air bath interior is shown in Fig. 2. The instrument is a collection of mechanical and electrical devices that are controlled by a dedicated internal computer. The system is based on a dual-cell arrangement where the main cell (from here on referred to as the pump cell [PC]) volume is varied by the vertical travel of a dynamically sealed piston driven by a computer-controlled stepping motor. 


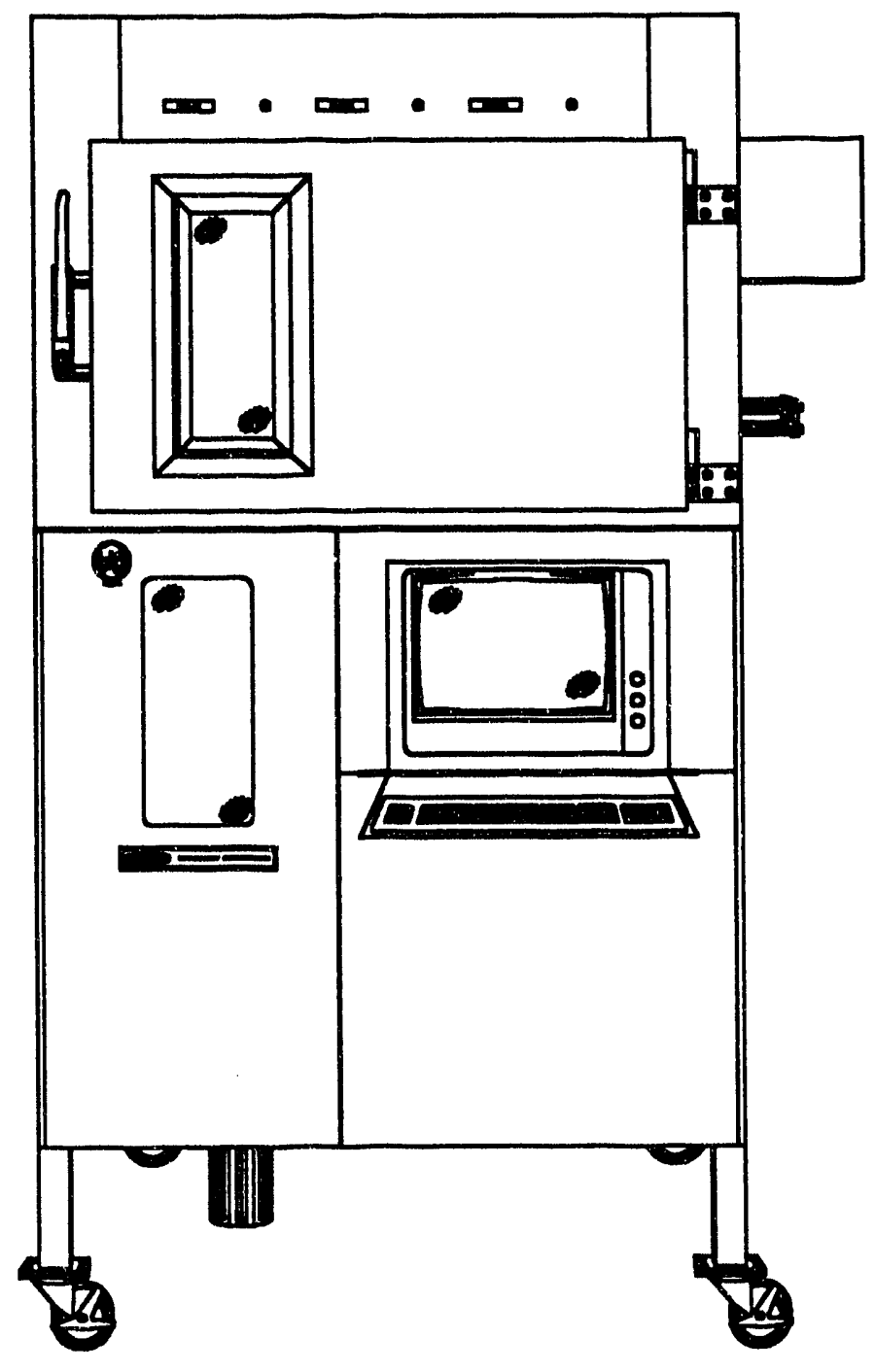

Figure 1. Ruska Model 2370-601 PVT System. 


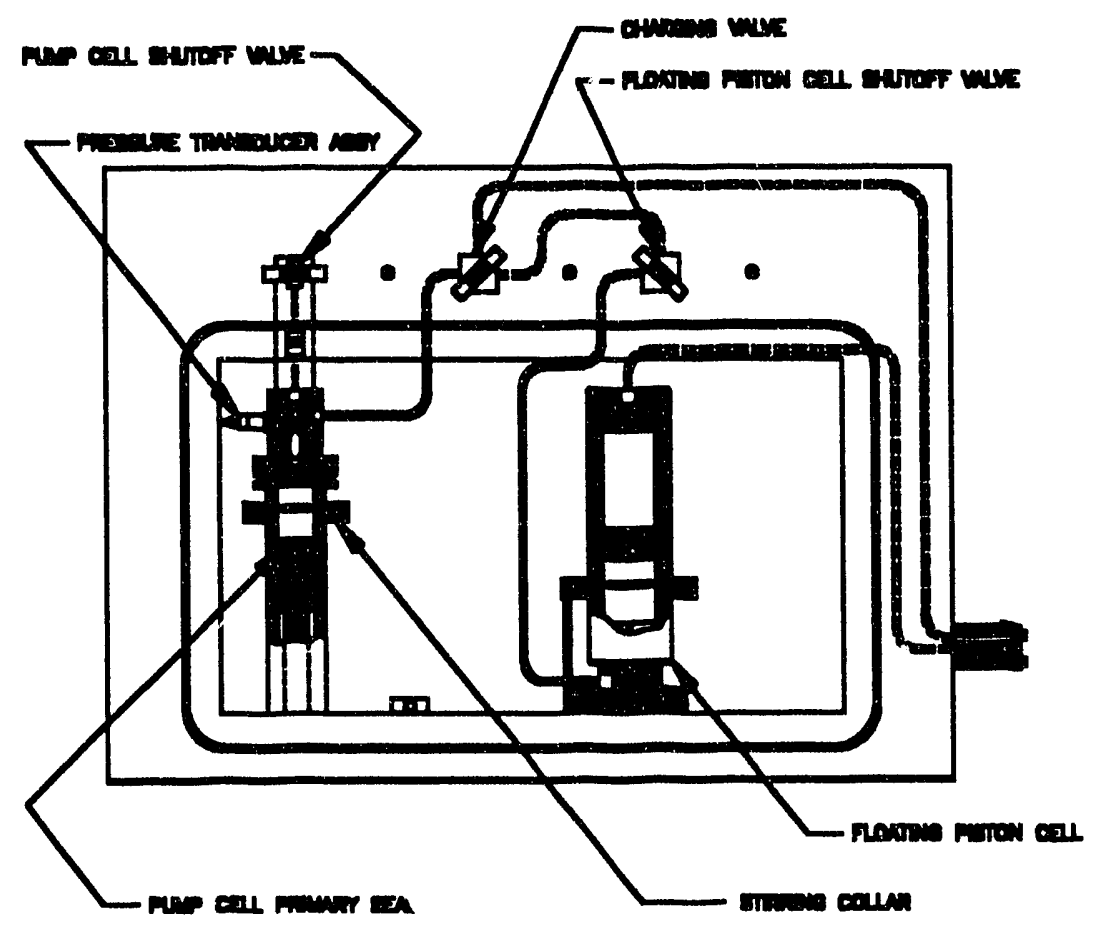

Figure 2. Ruska Model 2370-601 PVT System - Dual Cell Arrangement. 
The second cell contains a floating piston (called the floating piston cell [FPC]) whose movement is controlled with a hydraulic fluid. The pressure of the hydraulic fluid is in turn controlled by an external pump (Ruska Digital Pump Model 2216-603). The PC and FPC are both made out of Carpenter Pyrommet A-286 stainless steel and have nominal volumes of 400 and $600 \mathrm{cc}$, respectively. This gives a total volume of $1000 \mathrm{cc}$ when the two cells are used simultaneously (a $1600 \mathrm{cc}$ FPC is available to yield a $2000 \mathrm{cc}$ total volume).

The PC and FPC are connected by small bore tubing through a sapphire sight glass at the top of the PC. The top of the PC is connected to the bottom of the FPC. This configuration allows multiple phase volume measurements to be made by positioning the interface at the reference point in the sight glass. The on-board computer then calculates the volumes above and below the reference point with pressure and temperature compensation.

The cells are housed in an air bath that operates in a temperature range of 75 to $400^{\circ} \mathrm{F}$ with a temperature control of about $\pm 0.5^{\circ} \mathrm{F}$ (see Fig. 2). Resistance temperature devices (RTD) are placed in several locations in the air bath. The pump cell and the air bath temperatures are monitored and displayed continuously on the monitor screen to an $0.1^{\circ} \mathrm{F}$ resolution.

The pressure in the system is measured with a 0 to 10,000 psia temperature-compensated straingage type transducer with a $0.15 \%$ full scale (FS) accuracy rating. The transducer is frequently calibrated against a $0.05 \%$ FS Heise digital transducer connected to the external pump. The Heise gage is in turn calibrated against a Ruska 2375 dead weight gage with a $0.01 \%$ per reading accuracy. The transducer is located below the valve stem of the PC and pressure is displayed on the monitor with a 1 psia resolution.

The PC and FPC volumes are calculated based on the current values of pressure, temperature, and the piston position. The thermal and mechanical correction factors are based on the reported values of the thermal expansion coefficient and the modulus of elasticity of A-286 ${ }^{(1)}$ Carpenter stainless steel material.

The 2370 PVT system accomplishes fluid mixing both in the pump cell and floating piston cell by traversing a magnetic ring along the length of the cell. This is achieved by the magnetic coupling of an exterior magnetic ring to the interius magnet. The interior magnet agitates the fluid as a mobile baffle that moves up and down the $i$ ingth of the cylinder.

The 2370 uses an on-board dedicated computer to control and/or monitor a number of system parameters. The computer performs the following functions:

- monitor pressure, volume, and temperature and display on the computer screen,

- control pressure when in "Constant Pressure Mode;" in this mode, the pump cell pressure is automatically varied to maintain a set point pressure,

- control volume through the "Jog Mode" or the "Preset Mode;" the cell volumes are continually corrected for actual temperature and pressure so the displayed volumes on the screen are true volumes, 
- enhance operator safety by monitoring critical parameters such as system pressure and temperature and take corrective action in the event of an unsafe condition,

- perform calibrations; either automatically or by prompting the user through easy step by step procedures,

- communicate with an external computer to allow customized data acquisition and customized external control,

- control the magnetic stirrers,

- convert pressure and temperature to user specified units.

The following is a summary of the 2370 PVT apparatus specifications:

PRESSURE

Range

Resolution

Non-linearity and hysteresis

Thermal effects

Drift error
0-10,000 PSIA (standard)

1 PSIA (standard)

$\pm .05 \%$ F.S.

$\pm .05 \%$ F.S.

$\pm .2 \%$ F.S.

[Actual pressure resolution depends on the range of the transducer used; 10,000 psi range: 1.0 psi resolution; 1,000 to 9,999 psi range: 0.1 psi resolution; $0-999$ psi range: 0.01 psi resolution]

VOLUME

Pump Cell

Floating Piston Cell

Floating Piston Cell
$400 \mathrm{cc}$ (nominal)

$600 \mathrm{cc}$ (nominai, model 2370-601)

$1600 \mathrm{cc}$ (nominal, model 2370-602)

[Actual volumes will vary and must be determined by calibration]

TEMPERATURE

Range

Resolution

Accuracy

Control
Ambient to $400^{\circ} \mathrm{F}$

$0.1^{\circ} \mathrm{F}$

$\pm 0.5^{\circ} \mathrm{F}$

$\pm 0.5^{\circ} \mathrm{F}$ 


\section{MECHANICAL}

Height

Width

Depth

Depth

Weight $75^{\prime \prime}(191 \mathrm{~cm})$

$45^{\prime \prime}(114 \mathrm{~cm})$

$37 "(94 \mathrm{~cm})$ with doors

$31 "(79 \mathrm{~cm})$ doors removed

$960 \mathrm{lbs}(435 \mathrm{~kg}, 1350 \mathrm{lbs}$. crated)

[The front and back doors are easily removed by sliding them off their hinges]

\section{MAIN POWER}

Power:

$$
230 \mathrm{VAC} \pm 10 \%, 50 / 60 \mathrm{~Hz} \text { (single phase) }
$$

\section{ENVIRONMENT}

The model 2370-601 PVT System has the following environmental requirements:

1. Minimum warm-up time of 30 minutes.

2. Normal operating temperature range of $18^{\circ} \mathrm{C}$ to $28^{\circ} \mathrm{C}\left(65^{\circ} \mathrm{F}\right.$ to $\left.85^{\circ} \mathrm{F}\right)$.

3. Normal operating relative humidity range of $20 \%$ to $50 \%$, non-condensing.

4. Storage temperature range of $0^{\circ} \mathrm{C}$ to $55^{\circ} \mathrm{C}\left(32^{\circ} \mathrm{F}\right.$ to $\left.131^{\circ} \mathrm{F}\right)$.

\section{OPERATION}

The apparatus is designed to perform volumetric and phase behavior studies on i variety of fluids with special emphasis on those fluids typically encountered in petroleum reservoirs. The flexibility of the apparatus is such that fluids ranging from heavy crude oils (with viscosities of up to $2,000 \mathrm{cP}$ ) to lean gas condensates can be analyzed with this single system. Although the system is certainly not restricted to reservoir fluid analyses, the discussion on operations will focus on those studies typically associated with reservoir fluid PVT analyses. These studies include PV relationships, differential liberations, and constant volume depletions as well as bubble point and dew point determınations.

\section{PV Relationships}

A PV (Pressure-Volume) relationship (also known as a Constant Composition Expansion) is a measure of the compressibility of a constant-mass mixture of the sample in the single-phase and two-phase regions at reservoir temperature. This test could be performed exclusively in the pump cell. The floating piston cell would not be normally required for this study unless relative phase volume measurements a:e desired. The FPC could also be used as a sample recombination cell if desired. 
The test starts by pressurizing a known volume of the recombined reservoir fiuid at a pressure well above the bubble-point pressure of the oil. The pressure is then reduced in increments by expanding the mixture volume and allowing for equilibration to be achieved at each step. The total mixture volume is then recorded along with the equilibrium pressure. In the two-phase region, the gas and liquid phase volumes can also be measured by transferring the free gas into the floating piston cell at constant pressure. The phase volumes are then measured by positioning the interface at the sight glass reference point.

\section{$\underline{\text { Differential Liberation }}$}

This test is typically performed on crude oil samples and is best accomplished by using both the pump cell and the floating piston cells. Starting with a single-phase fluid (above its bubble point) in the pump piston cell the system is expanded in stages. The free gas phase at each stage is then isolated from the liquid phase by transferring the gas phase into the floating piston cell at constant overall volume and pressure. The phase interface is detected in the windowed cell top and the phases are isolated by the cell top valve. From the floating piston cell, the gas phase can then be conveniently expanded to a gas meter without risk of loosing any of the liquid phase. This procedure is a marked improvement over the current method which requires two operators and careful control of a meterir 3 valve. The key is the novel two cell arrangement which allows the isolation of the two phase:

\section{Constant Volume Depletion}

The depletion study for retrograde gas condensate systems can be performed using two methods:

1. The Straight Depletion

2. The Step-wise Depletion

For either condensate study method, the two cell arrangement is used. In the straight depletion, the gas is produced from the system by pressure decline at a very slow rate while maintaining constant system volume. At user specified pressure intervals the depletion is halted to make phase volume measurements.

The step-wise depletion is a series of equilibrium expansion steps where the gas and liquid phases are brought to equilibrium by agitation. The gas phase is then depleted to return to the original dew-point or saturation volume. Phase volumes are recorded at eacl: step. Neither of the two types of laboratory depletion processes mimic the reservoir performance during production. The straight depletion test yields optimistic results while the step-wise depletion is provides conservative results. The step-wise depletion is a procedure easier to perform and is accepted by most reservoir engineers as a close representation of reservoir performance. 


\section{Bubble Point Determination}

For crude oil systems, isothermal expansion of the liquid phase leads to the incipient formation of gas at the bubble point. This bubble-point pressure then indicates the saturation pressure and can be determined either visually or from the PV Relationship curve. For visual detection, the pump cell is used exclusively. The sapphire tube is at the very top of the cell which is where the first gas bubble will form. In most cases, however, the bubble point can be most easily determined from the PV curve. The transition from a single-phase liquid to two-phase liquid plus gas results in a drastic change in the overall mixture compressibility. This is manifested as a sharp break in the PV curve. The pressure at which the break occurs corresponds to the bubble point pressure.

\section{Dew Point D termination}

For retrograde gas condensate systems the reservoir temperature is above the critical temperature but below the cricondentherm so isothermal expansion of the gas phase leads to the formation of a condensate. Like the case for the bubble point, detection of the dew point can be made either visually or from the PV curve, but in the case of gas condensates, the break in the curve is usually not suarp. For visual detection both cells are required with the pump plunger in the fully embedded position and the bulk of the sample in the floating piston cell. In this araangement the sapphire tube is now at the bottom of the system and is thereby in position to detect the initial condensation.

\section{Applications}

The proposed PVT system has been designed with a strong emphasis on versatility to allow studies of non-petroleum fluids in addition to the full range of petroleum fluids. The system is ideal for any fluid phase equilibrium studies at elevated pressures and temperatures. These include experimental investigations on super-critical fluid extraction techniques, and a variety of other chemical processes where fluid phase equilibrium and volumetric data are required.

In addition, unique experimental possibilities now exist due to the dual cell configuration. For example, a sampling valve can easily be incorporated in the pressure line connecting the two cells to obtain microliter samples of any phase present in the system with volume compensation. Devices like capillary viscometer, hich-pressure densitometer, and surface tensiometer can also be connected in line between the two cells to provide a variety of physical property measurements.

\section{Commercial Viability}

The $2370 \mathrm{Hg}$-Free PVT system offers a broad range of capabilities in terms of PVT and other related thermophysical property measurements. Alhioough its primary market is in the petroleum industry, it has found its way into universities and other non-traditional petroleum organizations 
and companie: worldwide. There are eighteen (18) units that have been sold to date and has generated approximately $\$ 4 \mathrm{M}$ in sales (including accessories). Table 1 shows a breakdown of the field units in terms of country of location, specific organization, and number of units in-place.

Table 1. $2370 \mathrm{Hg}$-Free PVT Systems in the Field

\begin{tabular}{|l|l|c|}
\hline \multicolumn{1}{|c|}{ Country } & \multicolumn{1}{|c|}{ Organization } & $\begin{array}{c}\text { No. of } \\
\text { Units }\end{array}$ \\
\hline United States & Texas A\&M, Texas Tech, Philip Morris, Alyeska, and EG\&G & 5 \\
\hline Algeria & Sonatrach (Algerian National Oil Co.) & 1 \\
\hline Brazil & Petrobras (Brazilian National Oil Co.) & 1 \\
\hline China & $\begin{array}{l}\text { CNOOC, Tarim OC, Tuha OC, Beijing University, Weli } \\
\text { Centrir at Taizhou, Zhong Yuan OC, and Shengli OC }\end{array}$ & 7 \\
\hline Colombia & Equipetrol & 1 \\
\hline Malaysia & Universiti Kebangsan Malaysia & 1 \\
\hline Mexico & PEMFX (Mexican National Oil Co.) & 1 \\
\hline Oman & Sultan Qaboos University & 1 \\
\hline
\end{tabular}

\section{PERFORMANCE TESTING AND ENHANCEMENTS}

The design end development of the 2370 apparatus has been guided by the principle of continuous imprnvement from the prototype unit to its present configuration. A number of the changes that were implemented came as a result of the testing performed with hydrocarbon mixtures and some non-hydrocarbon gases.

Not surprisingly, a number of the technical difficulties that were encountered are portentously found in the rechnical reviews of Drs. J.J Ulbrecht (NIST/OERI) and J. M. Kincaid (SUNY at Sunny Brook) for the final evaluation of the project proposal to the DOE. These are: (1) the pump cell piston seal, (2) the drainage of samples and cleaning procedures after the completion of a test, and (3) air bath and fluid temperature homogeneity.

These issues along with other enhancements that came about as a result of the testing with real high-pressure fluid mixtures are described in the following sections. 


\section{Seal Material, Fluid Media, and Temperature. Compatibility}

The pump cell piston seal is perhaps the most critical part of the 2370 PVT system. The seal must hold pressure under both static and dynamic conditions, with fluid media ranging from dry gases to heavy liquids, and over a wide range of pressures and temperatures.

The original piston was designed to accommodate a lip-type spring-loaded U-ring seal made out of 1 flon. This piston-seal combination worked well with liquids but proved inadequate with esices especially at lower pressures. The seal apparently requires a threshold pressure before it yields positive sealing.

Further study of the seals available in the market was conducted to find a suitable seal that would provide positive sealing under the wide range of conditions that can be imposed on it. A new seal designed by Parker, called the Polypak, seemed to be a suitable candidate. The Parker Polypak seal is n combination of an $\mathrm{O}$-ring type synthetic rubber $\mathrm{O}$-spring and a conventional liptype seal. The design results in a squeeze-type seal which provides positive sealing at low pressure. Figure 3 shows a cross-sectional view of the Polypak.

The piston was redesigned with a groove that acsommodates the Polypak dimensions and tolerances. The Polypak material formulation chosen was Viton (V4208A90) because of its ability to operate up to $400^{\circ} \mathrm{F}$. Tests that were conducted with pure carbon dioxide using the V4208A90 compound, however, showed a slow leak occurring at pressures in excess of 5000 psia. Failure of the seal ultimately occurred after 3-4 days of continuous exposure. Inspection of the seal after failure strongly suggested the occurrence of the phenomenon called explosive decompression. Explosive decompression starts with the gas molecules diffusing into the seal matrix at a rate which is proportional to the applied pressure. When the pressure is rapidly relaxed, the gas molecules escape at a rate that can be orders of magnitude greater than the rate of diffusion, causing the seal to blister and eventually rupture.

Further tests were performed with three different material formulations. The new seals are made out of Fluorocarbon, Polymyte, and Fluoromyte formulations. The seals are listed on Table 2 in increasing relative hardness together with their corresponding Ruska numbers.

Table 2. Seal Materials for the Pump cell Piston.

\begin{tabular}{|l|l|c|}
\hline \multicolumn{1}{|c|}{ Material } & Parker Part Number & RIC Part Number \\
\hline Fluorocarbon & V420818701375 A90 & $72-682$ \\
\hline Fluorocarbon & V426618701375 A95 & $72-683$ \\
\hline Polymyte & Z465118701375 D53 & $72-684$ \\
\hline Fluoromyte & Z4ú5318701375 D58 & $72-685$ \\
\hline
\end{tabular}


Figure 3. Cross-Sectional View of the Polypak Seal.

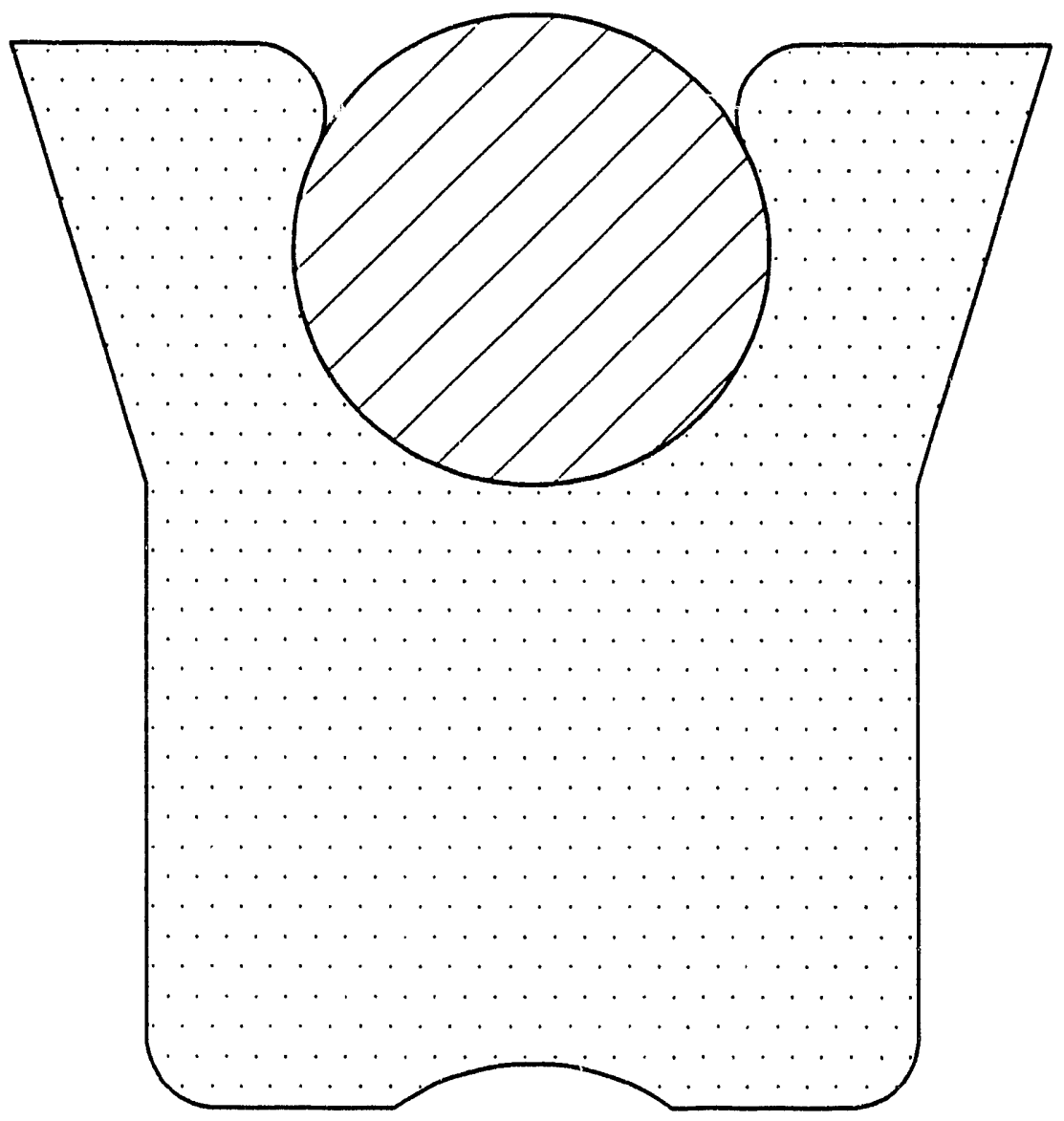


The Fluorocarbon seals offer the broadest range of temperature compatibility and are suitable for most hydrocarbon fluids. The Polymyte and Fluoromyte seals are made out of an elastoplastic material with very high tear strength and abrasion resistance which make them suitable for high pressure service. Polymyte is recommended for service in petroleum-based fluids, water-based fluids, phosphate ester fluids, some chlorinated fluids and solvents. The Fluoromyte material has a lower coefficient of friction than Polymyte due to lubricants added in the base material. In addition, Fluoromyte has high resistance to oxygen, ozone, petroleum and phosphate ester-based fluids. Tables 3 and 4 list the different seal materials versus fluid media and ranges of temperature compatibility.

The three materials, including the present seal used, are expected to cover the temperature and fluid compatibility range for applications in the petroleum, and to a large extent, the petrochemical industry. Experience has shown that the stiffer seals perform better with dry gases and should always be used with these media. All the seals showed durability during pressure cycles under moderate temperatures (up to $175^{\circ} \mathrm{F}$ ). Seal lifetime, however, is decreased considerably at temperatures above $250^{\circ} \mathrm{F}$. It is estimated that a seal lifetime of 1-2 months can be expected at moderate temperatures under normal usage. At the high temperature limit, it is recommended that the leak detection tests be performed before the start of a new test.

The piston underwent further redesign to accommodate the polymyte and fluoromyte seals. Although all four seals are identical in dimensions, the elastoplastic seals are very stiff and virtually inelestic. The piston was redesigned such that the top cap is removable. Figure 4 shows a schematic of the pump cell piston.

A new solid backup $\mathrm{ig}$ has also been designed. The dimensions and tolerance of the new backup ring was tigitivi... 30 that the cross-sectional area of contact with the seal is maximizer. This minimizes seal extrusion at higher pressures and temperatures while not affecting the seal performance at lower operating conditions. 


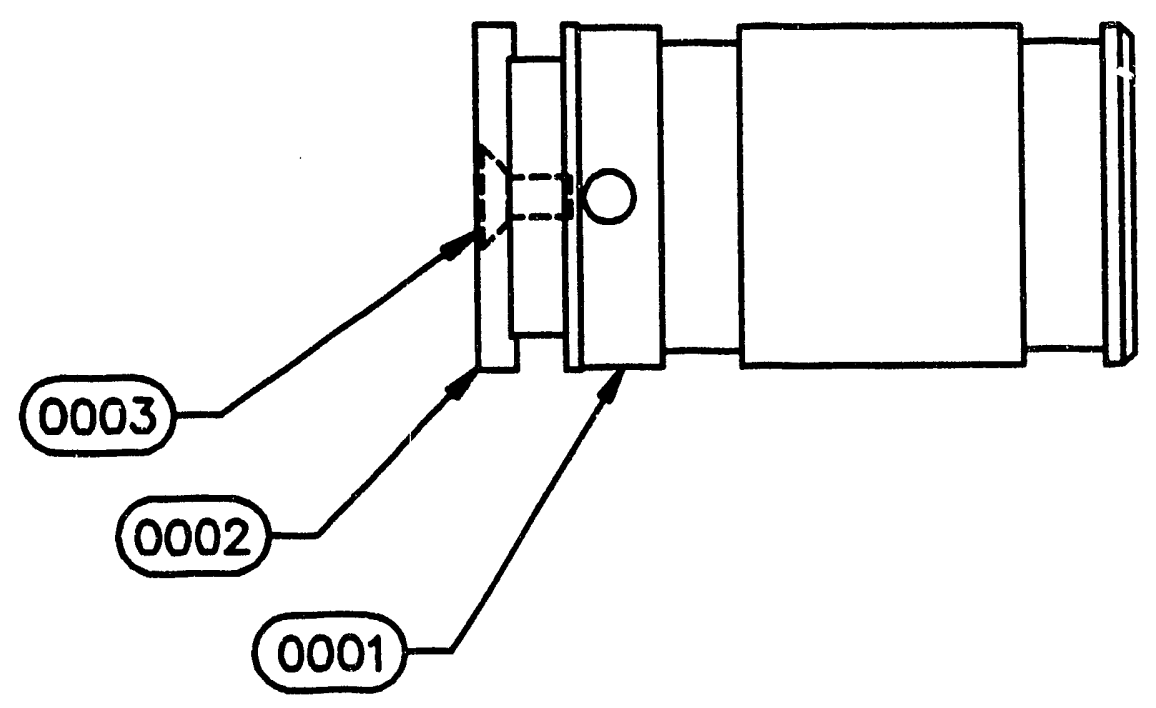

Sequence Number:

001 - Piston Body

002 - Piston End Cap

003 - Flat Head Socket Screw

Figure 4. 2370 Pump Cell Piston Design. 
Table 3. Parker Polypak Seal Material and Fluid Compatibility Table.

CHEMICALJFLUID MEDIA

V4208A90

(72-682)
V4266A95

(72-683)

\section{GENERAL FLUIDS}

Air and Dry Gas

Acid, weak $<50 \%$ conc.

Alcohols

Brake Fluid

Chlorine, Dry

Ethers

Freon refrigerants

Gasoline, leaded/unleaded

Glycols, ethylene based

Hydrogen

Hydroxides, weak $<50 \%$ conc.

Jet Fuel, JP-4, JP-5, JP-6

Kerosene

Ketones (e.g. Ácetone)

Oil, MIL-H-5606, R-3056,

Std. 417, Petroleum Base

Oil, Mineral Base

Oil, Petroleum Base

Aromatics, Lub., Fuel

Steam

Turpentine

Water, Hot $>180^{\circ} \mathrm{F}$

Water, Cold $<150^{\circ} \mathrm{F}$

WATER-GLYCOL FLUIDS

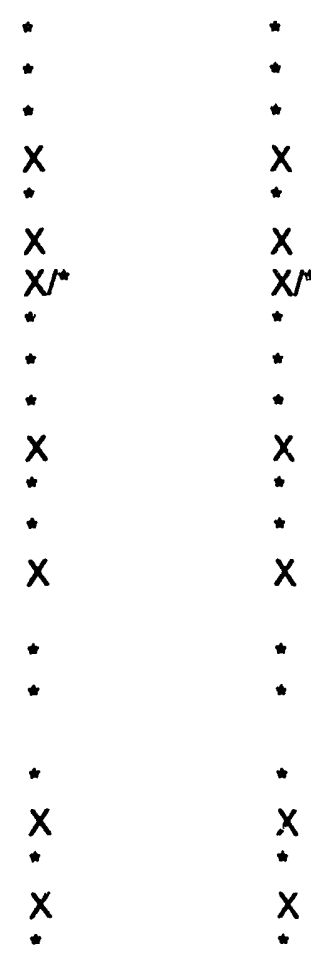

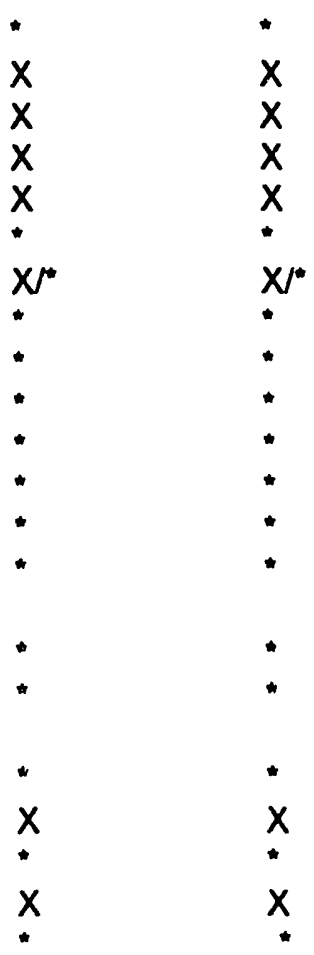

Fyre-Safe 160, 225

Fyreguard 150, 200, G-200

Houghto-Safe 500, 600

Hydrolube 150LT, 200LT,

$$
275 \mathrm{LT}, 300 \mathrm{LT}
$$

Saritosaie W/G15, W/G20,

W/G30

WATER-IN-OIL EMULSION FLUIDS

Fyre-Safe 500

Gulf FR Fluid

Houghto-Safe 5000

Hulsafe 500, 600

Inverse Emulsion

Invert Emulsion

$x$

$x$

$x$

$x$

$x$

$\begin{array}{ll}x & x \\ x & x \\ x & x \\ x & x \\ x & x \\ x & x\end{array}$

AIRCRAFT-TYPE FLUIDS

Aerosafe 2300, ER

Phosphate Ester Hydraulic

Fluid

Skydrol 500B4, 500C $x \quad x$

$x$

$x$

$x$
$x$ $x$

$x$

$\mathrm{X}$

$x$

$x$

$x$

$x$

$x$

$x$ 
CHEMICAL/FLUID MEDIA

Hyjet W, III, IVA

$x$

$x$

PHOSPHATE-ESTER OIL BLENDS

Phosphate Ester, Base Fluid

Pydraul 230-C, 312-C, 540-C

Sunguard 350 Safety Fluid

Vital Hydraulic Fluid

$\begin{array}{lll}* & * & * \\ : & \text { : } & \text { : }\end{array}$

\author{
Fluid Compatibility Rating Key \\ - Recommended \\ $X$ Unsatisfactory \\ X ${ }^{*}$ Minor/Moderate Effect
}

Table 4. Seal Material versus Temperature Compatibility Table. ${ }^{1}$

\begin{tabular}{|l|ll|}
\hline \multicolumn{1}{|c|}{ COMPOUND } & \multicolumn{2}{|c|}{ TEMPERATURE RANGE } \\
\hline V4208A90 (Fluorocarbon) & $-20^{\circ} \mathrm{F}$ to $400^{\circ} \mathrm{F}$ & $\left(-29^{\circ} \mathrm{C}\right.$ to $\left.204^{\circ} \mathrm{C}\right)$ \\
\hline V4266A95 (Fluorocarbon) & $-20^{\circ} \mathrm{F}$ to $400^{\circ} \mathrm{F}$ & $\left(-29^{\circ} \mathrm{C}\right.$ to $\left.204^{\circ} \mathrm{C}\right)$ \\
\hline Z4651D53 (Polymyte) & $-65^{\circ} \mathrm{F}$ to $275^{\circ} \mathrm{F}$ & $\left(-54^{\circ} \mathrm{C}\right.$ to $\left.135^{\circ} \mathrm{C}\right)$ \\
\hline Z4653D58 (Fluoromyte) & $-65^{\circ} \mathrm{F}$ to $300^{\circ} \mathrm{F}$ & $\left(-54^{\circ} \mathrm{C}\right.$ to $\left.149^{\circ} \mathrm{C}\right)$ \\
\hline
\end{tabular}

\title{
Sanıple Drainage and Cleaning Procedures
}

There were initial concerns with regards to the drainage of the sample and the cleaning of the system at the end of an experiment. The original design of the pump-cell top coupled with the plumbing configuration allowed only for entry and exit of fluid through the same route. The initial introduction of a sample to the system contaminated the flow loop between the pump cell and the floating piston cell. Also, there was no effective way to rinse the two cells with a solvent that sweeps the flow lines without recontaminating the same lines when the dirty solvent is purged from the system.

Ideally, the flow lines leading to the two cells should have an exit port which would allow for the unidirectional flow of fluids. This would allow for the dirty solvent to be purged downstream

\footnotetext{
${ }^{1}$ Source: Parker Polypak Seal Design Handbook (PPD 3800)
} 
of the flow loop between the two cells. Repeated rinse-and-purge sperations with both cells at minimum volume positions would then dilute and displace the previous test fluid. This can then be followed by a hard vacuum for 10-15 minutes. Complete dismantling of the cells for cleaning would not be necessary unless the fluids are completely different.

This task was accomplished by the addition of a bleed port with a Ruska needle valve on the top of the pump cell (PC). The bleed port is located above the valve seat of the pump cell which allows for the flow line to be purged and rinsed with a solvent after the initial introduction of fluid into the primary (PC) or secondary (FPC) cell.

The valve seat and valve stem on the $\mathrm{F}^{\prime} \mathrm{C}$ were also changed to a metering design. This allows for a finer flow control to be achieved even under high pressure. The metering capability is essential during a differential liberation test, for instance, where the free gas phase in the PC is isolated from the liquid phase by transfer to the FPC at constant pressure. The transfer has to be accomplished without allowing a drop of liquid to be carried into the FPC.

\section{Air Bath and Fluid Temperature Homogeneity}

Temperature profile measurements were performed inside the air bath on the prototype unit to determine the optimum parameter settings of the temperature controller. Additional resistance temperature devices (RTDs) were placed on several locations in the oven and the temperature monitored along with the system RTDs on the PC and oven. The readings were recorded and compared with the set point temperature. Optimization of the proportional, integral, and derivative (PID) constants on the controller yielded a maximum gradient of $1.7^{\circ} \mathrm{F}$ between the pump cell and the air bath over the range of $150-350^{\circ} \mathrm{F}$.

During the middle part of 1992, Ruska decided to manufacture the oven itself due to problems encountered with the outside vendor at the time. Initial tests with the first unit that was built after the change showed a large temperature gradient between the air bath and the pump cell temperatures. Velocity profile measurements revealed that air circulation close to the oven floor was poor. This is apparently due to short circuiting and occurrence of stagnant regions in the air ducts. A close inspection of the flow path revealed sharp corners and flow constriction due to the alignment of the fin heaters.

Baffles were then placed strategically along the flow path and the 90 degree corners were rounded. These changes greatly improved the air flow and resulted in a maximum temperature gradient of no more than $1.6^{\circ} \mathrm{F}$ between the pump cell and the air bath.

It was also suspected at the time that a uniform air temperature does not guarantee a uniform fluid temperature. Heat loss occurs on the piston itself through the pump shaft. $A$ band heater located at the base of the pump cell seeks to offset this loss. How effectively is does this task was largely unquantified.

Tests were performed to measure the temperature profile of the fluid in the pump cell. The fluid used is a Dow Corning synthetic oil with a viscosity of $500 \mathrm{cP}$ at ambient temperature. The 
pump cell was filled with the oil to its maximum volume of approximately $360 \mathrm{cc}$ with the piston top positioned at approximately the same, lane as the, base of the oven. The sight glass was removed from the cell top and an RTD was inserted through the opening and immersed in the fluid. Temperatures were measured at the bottom of the cell (RTD piaced on top of the piston) and at a point 3 inches down from the top of the cell. The pump cell and the air bath temperatures were also recorded at a set point of $300^{\circ} \mathrm{F}$. Temperatures were recorded after the fluid has been stirred. Table 5 summarizes the results of the measurements.

Table 5. Fluid Temperature Profile in the Pump Cell

\begin{tabular}{||c|c|c|c|c|c|}
\hline \multicolumn{6}{|c|}{ Fluid Temperature Profile ( $\left.{ }^{\circ} \mathbf{F}\right)$} \\
\hline Set Point & Oven RTD & $\begin{array}{c}\text { Pump Cell } \\
\text { RTD }\end{array}$ & $\begin{array}{c}\text { Fluid } \\
\text { Top }\end{array}$ & $\begin{array}{c}\text { Fluid } \\
\text { Bottom }\end{array}$ & Gradient \\
\hline 300.0 & 299.5 & 298.2 & 301.0 & 299.2 & 1.8 \\
\hline
\end{tabular}

The data in itself is very limited although the gradient is large enough to warrant further study. The in-house unit is currently being upgraded to include all the changes that were implemented including the ones that are outside the scope of the research grant. Further tests will be performed as the new unit becomes available (first quart + of 1993).

\section{APPLICATIONS TESTING AND COMPARISON}

The design of the $2370 \mathrm{Hg}$-Free PVT apparatus is essentially one of systems engineering. The subcomponents of the apparatus has been adapted from stable technologies which facilitates the manufacturing and documentation processes to provide a functional measurement system.

Nevertheless this ensemble of robust and proven technologies, in toto, lies outside the boundary of conventional paradigm by virtue of its departure from traditional equipment design and operation. The new system is therefore burdened to prove that it performs as good, if not better, when compared to a mercury-based apparatus.

The 2370 system was therefore subjected to a series of tests to develop the confidence level on the system's functionality. These included the density measurements for a pure fluid which was then compared to published literature data and the predictions of an equation of state. Routine reservoir fluid analyses were also conducted on a black oil and a gas condensate mixture. The results of the black oil and gas condensate studies were then compared to the data obtained from parallel tests performed on a mercury-based instrument. The testing and comparison studies has also resulted in new measurement protocols for the new instrument. The results of the study are presented in the following sections. 


\section{Density Measurements on Pure Propane}

The propane used in the study was obtained from Scott Specialty Gases and has a stated purity of $99.5 \%$. No further purification of the material was performed. Propane was introduced into an initially vacuumed pump cell and floating piston cell. The system pressure measured by the $0.15 \%$ strain-gage transducer was then compared to the $0.05 \%$ Heise gage reading on the external pump. The strain-gage transducer reading was found to be within its stated accuracy. The system was then thermally equilibrated at the run temperature of $116.4^{\circ} \mathrm{F}$. The density of $\mathrm{C}_{3}$ was obtained from the literature ${ }^{(1)}$ at the initial pressure (based on the more accurate Heise reading) and run temperature. This value was used to calculate the mass of propane introduced in the pump cell. The calculated mass was then used to establish the density of the material at different pressures along the isotherm during the test.

The results of the pressure traverse along the subcritical isotherm of $116.4^{\circ} \mathrm{F}$ for pure $\mathrm{C}_{3}$ are summarized in Fig. 5. Pressure/volume measurements were conducted below the $\mathrm{C}_{3}$ reported bubble point pressure of $235 \mathrm{psia}$ at $116.4^{\circ} \mathrm{F}$ (2) $^{(2)}$ The measured densities were compared to the prediction of Supertrapp, ${ }^{(3)}$ an equation of state based on an extended Corresponding States Principle, and with published literature values. ${ }^{(2)}$ The comparison of the measured densities are given in Tables 6 and 7, respectively. The experimental densities compared favorably with the predictions of Supertrapp and with the literature values. The average absolute percent deviations (AAPD) based on the comparison with the EOS and literature values are $1.9 \%$ and $2.1 \%$, respectively.

Table 8 shov's an error analysis of the data based on a worse-case scenario. The deviation between the measured and reference values is duc to the contributions in pressure, temperature, and volume (the state variables of the system) measurement errors. An estimate of the maximum error contribution due to an error in measuring any one of the state variables shows that the measured density values are most sensitive to the pressure reading. For the data point at 103 psia (see Tables 6 and 7), the measured specific volume of $73.38 \mathrm{~cm}^{3} / \mathrm{g}$ is 2.96 and $3.30 \mathrm{~cm}^{3} / \mathrm{g}$ less than the EOS-predicted and literature values, respectively. The analysis shows that the pressure reading could have been off by $4.1 \mathrm{psia}$ from the intrinsic value to account for the deviation. This falls within the stated pressure measurement accuracy of \pm 15 psia.

For the same data point, the temperature would have to be off by $17.4^{\circ} \mathrm{F}$ to account for the density discrepancy. A comparison of the pump cell temperature as measured by the pressure transducer RTD against a platinum resistance thermometer standard with a $\pm 0.05^{\circ} \mathrm{F}$ accuracy showed a maximum difference of $0.95^{\circ} \mathrm{F}$ (compensated for the reference standard accuracy) at $350^{\circ} \mathrm{F}$ nominal set point temperature. Thus, if the temperature of the system was off by the maximum value, it would only account for $0.2 \%$ of the observed discrepancy for the data point at 103 psia.

If the pressure and temperature readings are taken as the intrinsic values, then the volume reading is around $4.5 \mathrm{~cm}^{3}$ less than what it should be to account for the density discrepancy. Preliminary test results on the volume reading accuracy tends to suggest that this is an unlikely scenario. A volume reading accuracy of $\pm 0.1 \mathrm{~cm}^{3}$ is stated based on the best estimate from available results. 


\section{Pure Propane System Pressure-Density Relation @ 116 F}

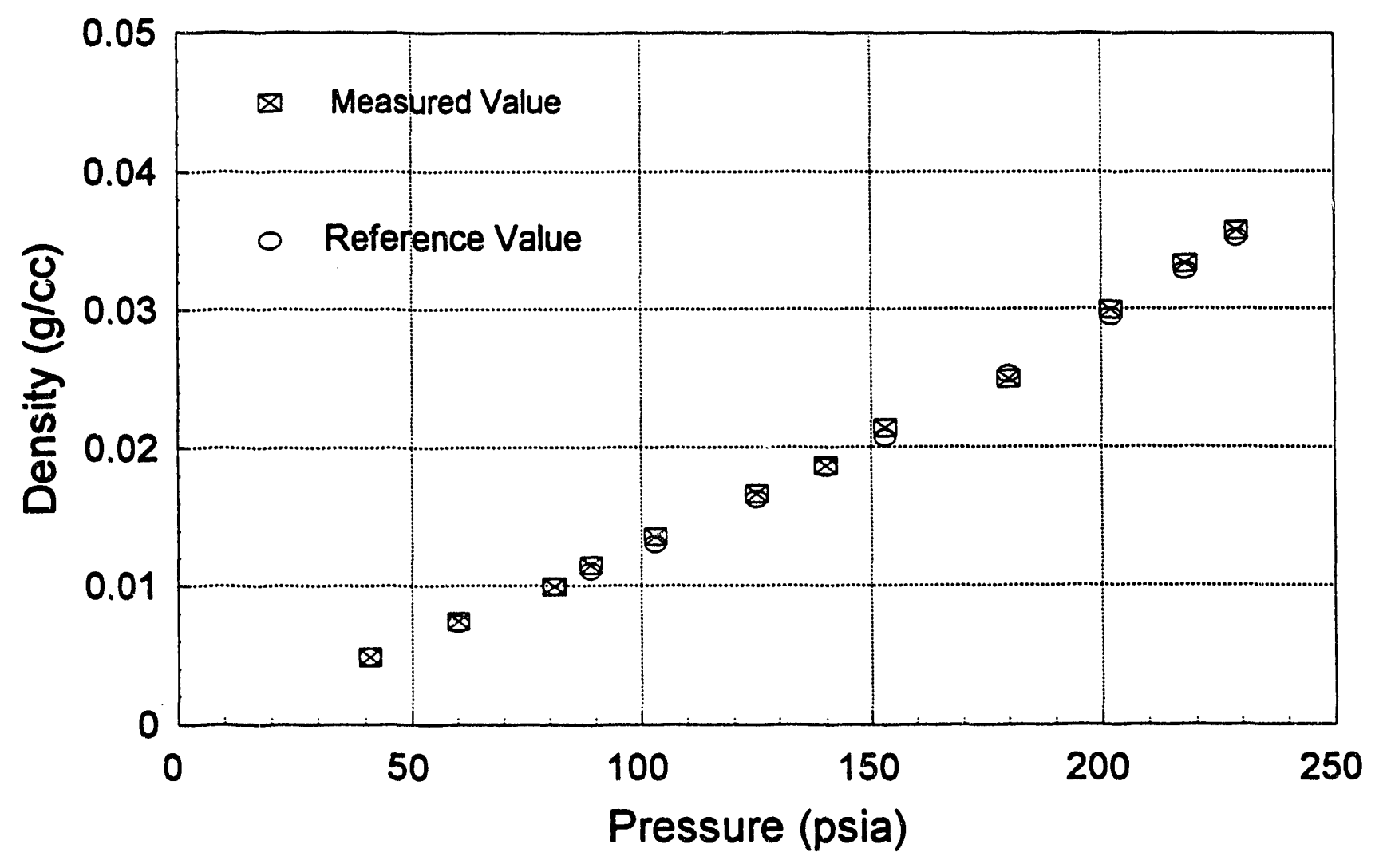

Figure 5. Pressure-Density Relation for Propane at $116^{\circ} \mathrm{F}$. 
Table 6. Comparison of Measured and EOS-Predicted Specific Volume at a Subcritical Isotherm of $116.4^{\circ} \mathrm{F}$ for Propane

\begin{tabular}{|c|c|c|c|}
\hline $\begin{array}{c}\text { Pressure } \\
(\mathrm{psia})\end{array}$ & $\begin{array}{c}\text { Spec. Vol } \\
\left(\mathrm{cm}^{3} / \mathrm{g}\right)\end{array}$ & $\begin{array}{c}\text { Spec. Vol }{ }^{\mathrm{I}} \\
\left(\mathrm{cm}^{3} / \mathrm{g}\right)\end{array}$ & $\Delta \%$ \\
\hline 41 & 203.16 & 204.08 & -0.5 \\
\hline 60 & 133.42 & 136.99 & -2.6 \\
\hline 81 & 100.07 & 100.00 & 0.1 \\
\hline 89 & 86.72 & 90.09 & -3.7 \\
\hline 103 & 73.38 & 76.34 & -3.9 \\
\hline 125 & 60.04 & 61.35 & -2.1 \\
\hline 140 & 53.37 & 53.76 & -0.7 \\
\hline 153 & 46.70 & 48.31 & -3.3 \\
\hline 180 & 40.03 & 39.53 & 1.3 \\
\hline 202 & 33.36 & 33.90 & -1.6 \\
\hline 218 & 30.02 & 30.49 & -1.5 \\
\hline 229 & 28.02 & 28.41 & -1.4 \\
\hline Average Absolute Percent Deviation $=1.9 \%$ \\
\hline
\end{tabular}

$\S$ Measured Value

I EOS-Predicted Value ${ }^{(3)}$ 
Table 7. Comparison of Measured and Literature Specific Volume at a Subcritical Isotherm of $116.4^{\circ} \mathrm{F}$ for Propane

\begin{tabular}{|c|c|c|c|}
\hline $\begin{array}{c}\text { Pressure } \\
(\text { psia })\end{array}$ & $\begin{array}{c}\text { Spec. Vol } \\
\left(\mathrm{cm}^{3} / \mathrm{g}\right)\end{array}$ & $\begin{array}{c}\text { Spec. Vol } \\
\left(\mathrm{cm}^{3} / \mathrm{g}\right)\end{array}$ & $\Delta \%$ \\
\hline 41 & 203.16 & 205.38 & -1.1 \\
\hline 60 & 133.42 & 137.76 & -3.2 \\
\hline 81 & 100.07 & 99.96 & 0.1 \\
\hline 89 & 86.72 & 90.24 & -3.9 \\
\hline 103 & 73.38 & 76.68 & -4.3 \\
\hline 125 & 60.04 & 61.36 & -2.2 \\
\hline 140 & 53.37 & 53.71 & -0.6 \\
\hline 153 & 46.70 & 47.87 & -2.4 \\
\hline 180 & 40.03 & 38.68 & 3.5 \\
\hline 202 & 33.36 & 33.46 & -0.3 \\
\hline 218 & 30.02 & 30.44 & -1.4 \\
\hline 229 & 28.02 & 28.67 & -2.3 \\
\hline Average Absolute Percent Deviation $=2.1 \%$ \\
\hline
\end{tabular}

$\S$ Measured Value

Interpolated Literature Value ${ }^{(2)}$ 
Table 8. Sensitivity and Error Analysis of the Data Point with Maximum Absolute Deviation from the EOS-Predicted Value

\begin{tabular}{|c|c|}
\hline \multicolumn{2}{|c|}{ State Variables and Measured Density } \\
\hline $\begin{array}{l}P=103 \text { psia, } V=110.0 \mathrm{cc}, \\
T=116.4^{\circ} \mathrm{F}\end{array}$ & $\begin{array}{l}v=73.38 \mathrm{cc} / \mathrm{g} \text { (measured) } \\
v=76.34 \mathrm{cc} / \mathrm{g} \text { (reference) }\end{array}$ \\
\hline \multicolumn{2}{|c|}{ Pressure Reading Sensitivity } \\
\hline $\mathrm{T}=116.4^{\circ} \mathrm{F}, \mathrm{v}=73.38 \mathrm{cc} / \mathrm{g}$ & $P^{\prime}=107.1$ psia \\
\hline Pressure Reading Discrepancy: & $\Delta \mathrm{P}=4.1 \mathrm{psia}$ \\
\hline Pressure Reading Accuracy: & $\pm 0.15 \%$ FS or $\pm 15 \mathrm{psia}$ \\
\hline \multicolumn{2}{|c|}{ Temperature Reading Sensitivity } \\
\hline$P=103$ psia, $U=73.38 \mathrm{cc} / \mathrm{g}$ & $\mathrm{T}^{\prime}=99^{\circ} \mathrm{F}$ \\
\hline Temperature Reading Discrepancy: & $\Delta \mathrm{T}=17.4^{\circ} \mathrm{F}$ \\
\hline Temperature Reading Accuracy: & $\pm 0.5^{\circ} \mathrm{F}$ \\
\hline \multicolumn{2}{|c|}{ Volume Reading Sensitivity } \\
\hline $\begin{array}{l}\mathrm{P}=103 \text { psia, } \dot{U}=76.34 \mathrm{cc} / \mathrm{g}, \\
\mathrm{T}=116.4^{\circ} \mathrm{F}\end{array}$ & $V^{\prime}=114.44 \mathrm{cc}$ \\
\hline Volume Reading Discrepancy: & $\Delta V=4.44 \mathrm{cc}$ \\
\hline Volume Reading Accuracy: & $\pm 0.1 \mathrm{cc}$ \\
\hline
\end{tabular}


Further tests are planned to establish the value of this parameter with a higher degree of confidence.

\section{Black Oil Testing and Comparison of Data with a Mercury-Based Instrument}

Reservoir fluid analyses were conducted on a synthetic black oil system. The mixture was synthesized from a special gas blend and a stock tank oil (STO) from the Wasson field in Gaines County, West Texas.

The composition of the STO, determined by simulated distillation, is given in Table 9 along with the composition of the gas mixture added to it. Table 10 shows a summary of the STO and gas mixture physical properties.

The recombination was performed directly in the 2370 apparatus. A carefully measured volume of the STO was loaded in the PC while the gas mixture was stored in the FPC. The gas was then metered into the $P C$ at a working pressure of 5000 psia and $85^{\circ} \mathrm{F}$. The amount of gas added yielded a gas/oil ratio of 250 standard cubic feet of gas per barrel of STO at $60^{\circ} \mathrm{F}$. The PC contained a final volume of $104.16 \mathrm{cc}$ of recombined oil at $5000 \mathrm{psia}$ and $85^{\circ} \mathrm{F}$.

The sample was then thermally expanded to the run temperature of $145^{\circ} \mathrm{F}$ while maintaining 5000 psia. The stirrer was turned on and the sample was allowed to equilibrate overnight. The singlephase fluid expanded to a volume of $106.69 \mathrm{cc}$ at 5000 psia and $144.4^{\circ} \mathrm{F}$. Constant composition expansion and differential liberation tests were then performed on the recombined oil. A summary of the PVT data is presented in Table 11.

The average single-phase compressibility of the recombined oil is given in Table 12. The constant composition expansion test on the recombined oil yielded a bubble-point pressure of 1352 psia. The pressure-volume relations are presented on Table 13 and shown graphically in Fig. 6-7.

The expanded mixture was then re-pressurized into a single-phase fluid at the working pressure of 5000 psia. To ensure that the mixture is homogeneous, further mixing was achieved by transferring the mixture back and forth between the PC and the FPC. The amount of material left behind in the line and the dead space between the PC and FPC was accounted for in the material balance calculations.

The mixture was then subjected to a differential liberation test at $145^{\circ} \mathrm{F}$. A total of 254 standard cubic feet of gas were liberated per barrel of residual oil at $60^{\circ} \mathrm{F}$ upon completion of the test. The relative oil volume was calculated to be 1.1325 barrels of saturated fluid per barrel of residual oil at $60^{\circ} \mathrm{F}$. The specific gravity of the liberated gas was measured during the test. A summary of the differential liberation data is presented in Table 14 and Figs. \&-12.

The result of the differential vaporization test is consistent with the behavior of a low GOR black oil system at moderate temperatures. The total volume of gas evolved during the test is close to the volume added in solution due to the relatively moderate rur, temperature. 


\section{Pressure-Volume Relation}

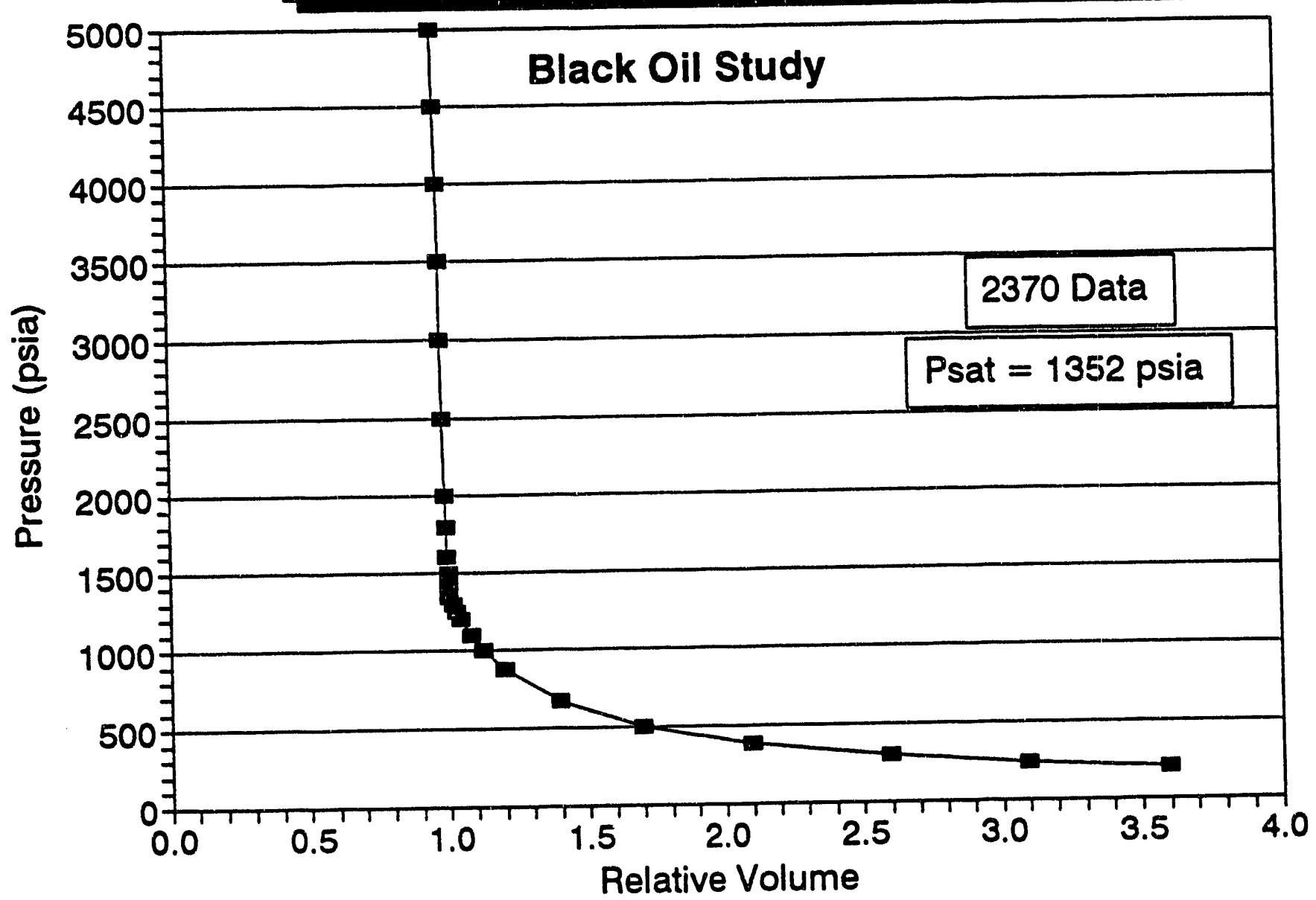

Figure 6. Pressure-Relative Volume Relation for the Black Oil System at $145^{\circ} \mathrm{F}$. 


\section{Pressure-Volume Relation}

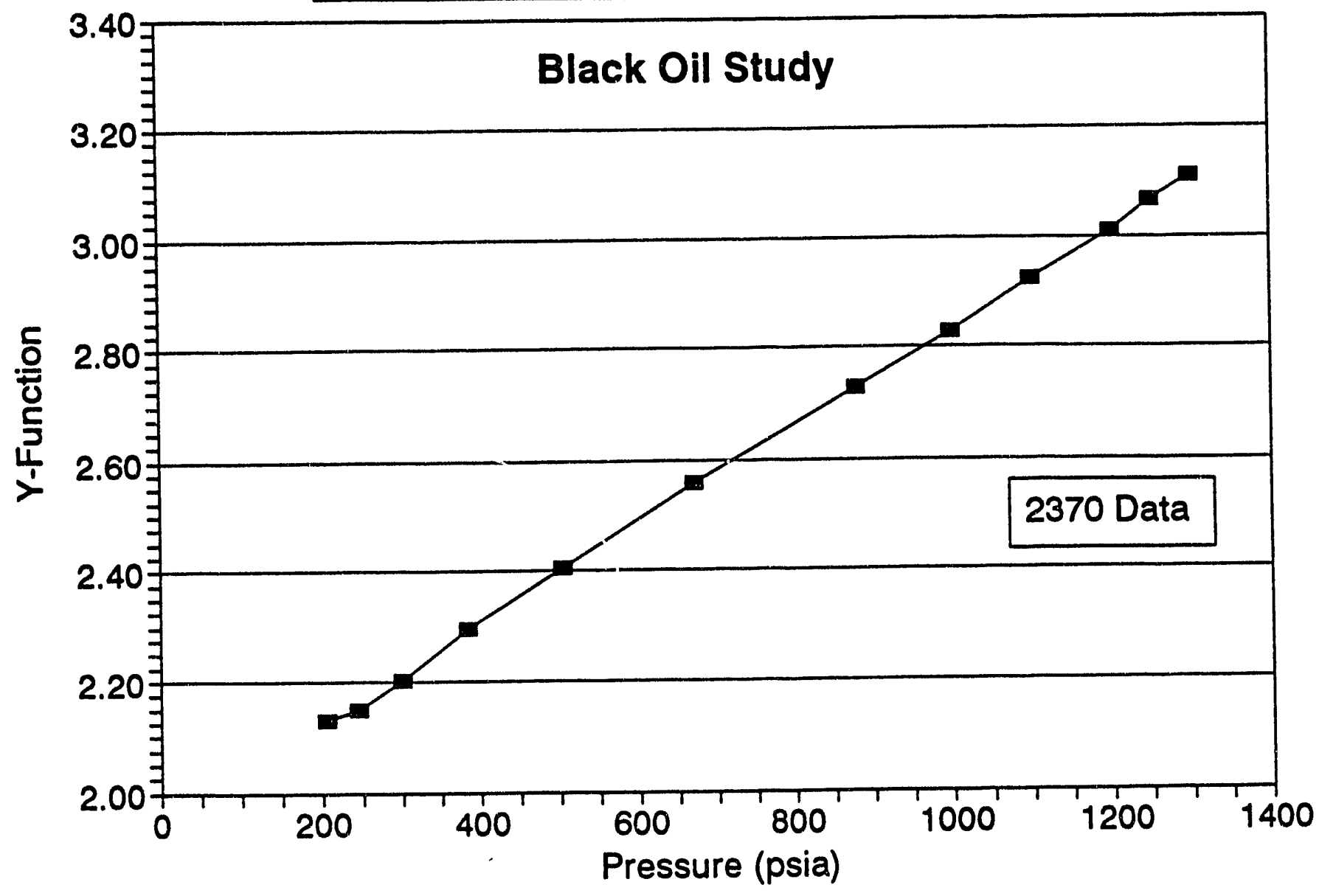

Figure 7. Y-Function Relation for the Black Oil System at $145^{\circ} \mathrm{F}$. 


\section{Differential Vaporization Liquid and Total Relative Volumes}

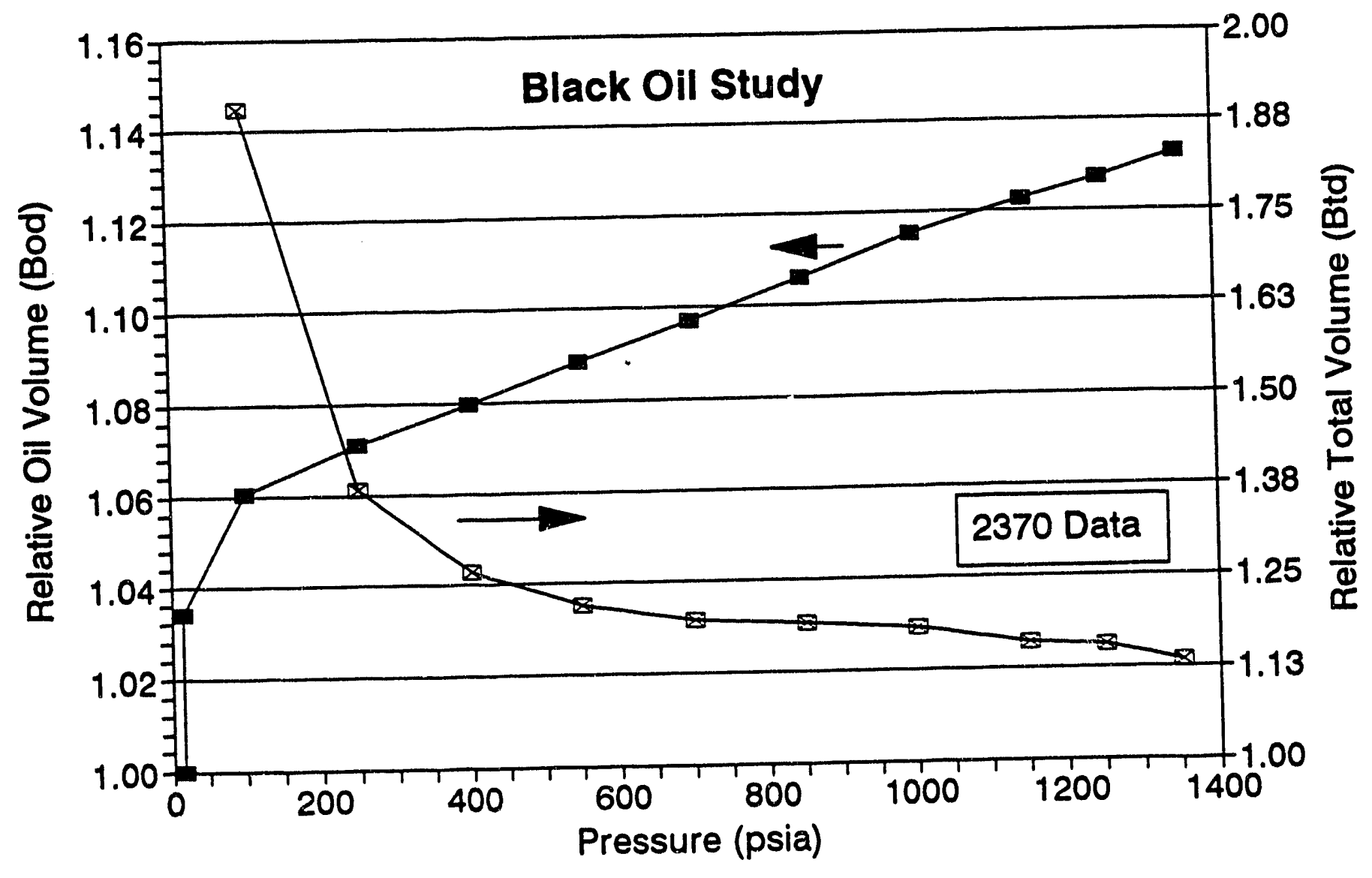

Figure 8. Differential Liberation Total and Relative Volume Data. 


\section{Differential Vaporization Solution Gas Oil Ratio}

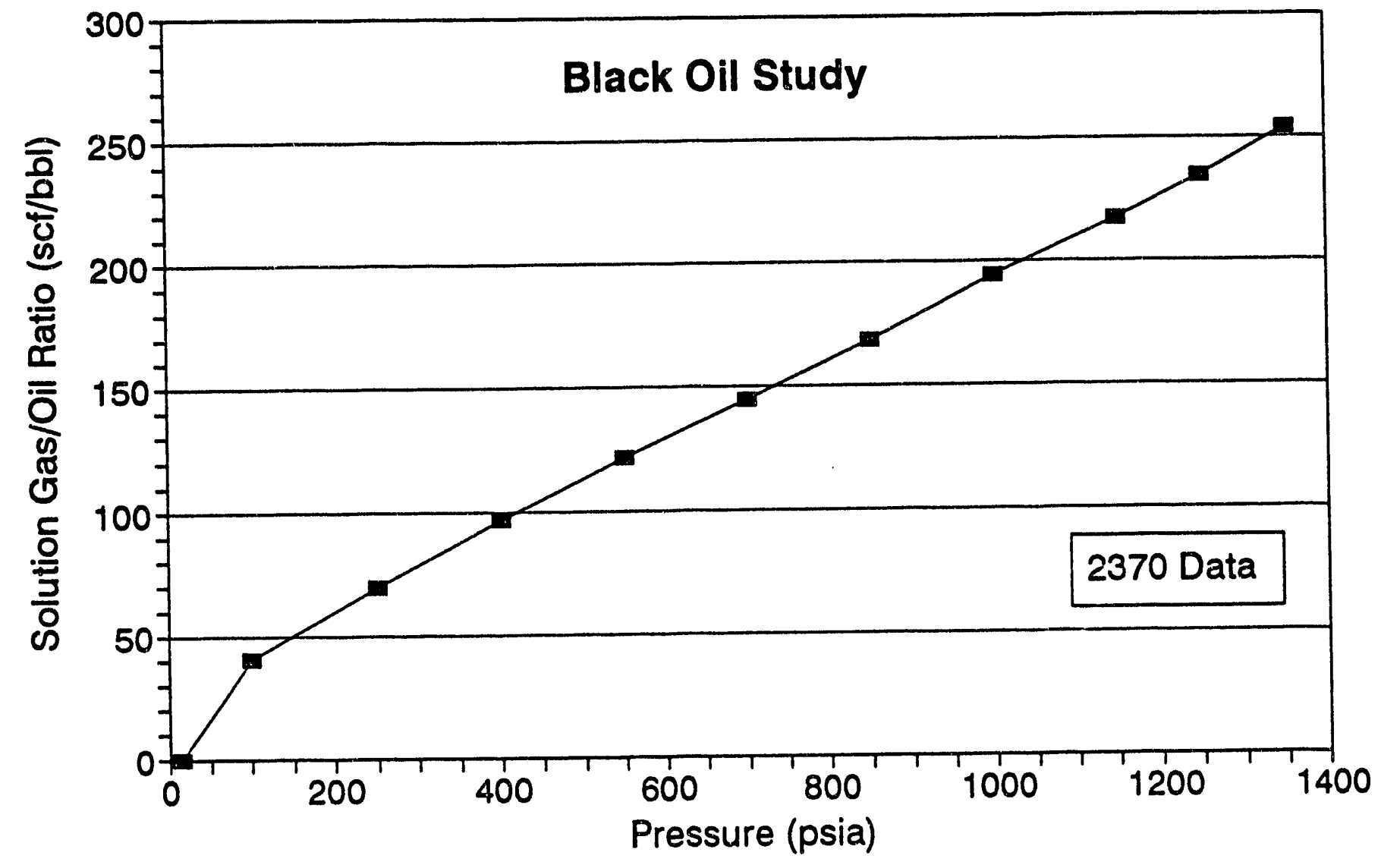

Figure 9. Differential Liberation Solution Gas/Oil Ratio. 


\section{Differential Vaporization Liberated Gas Gravity}

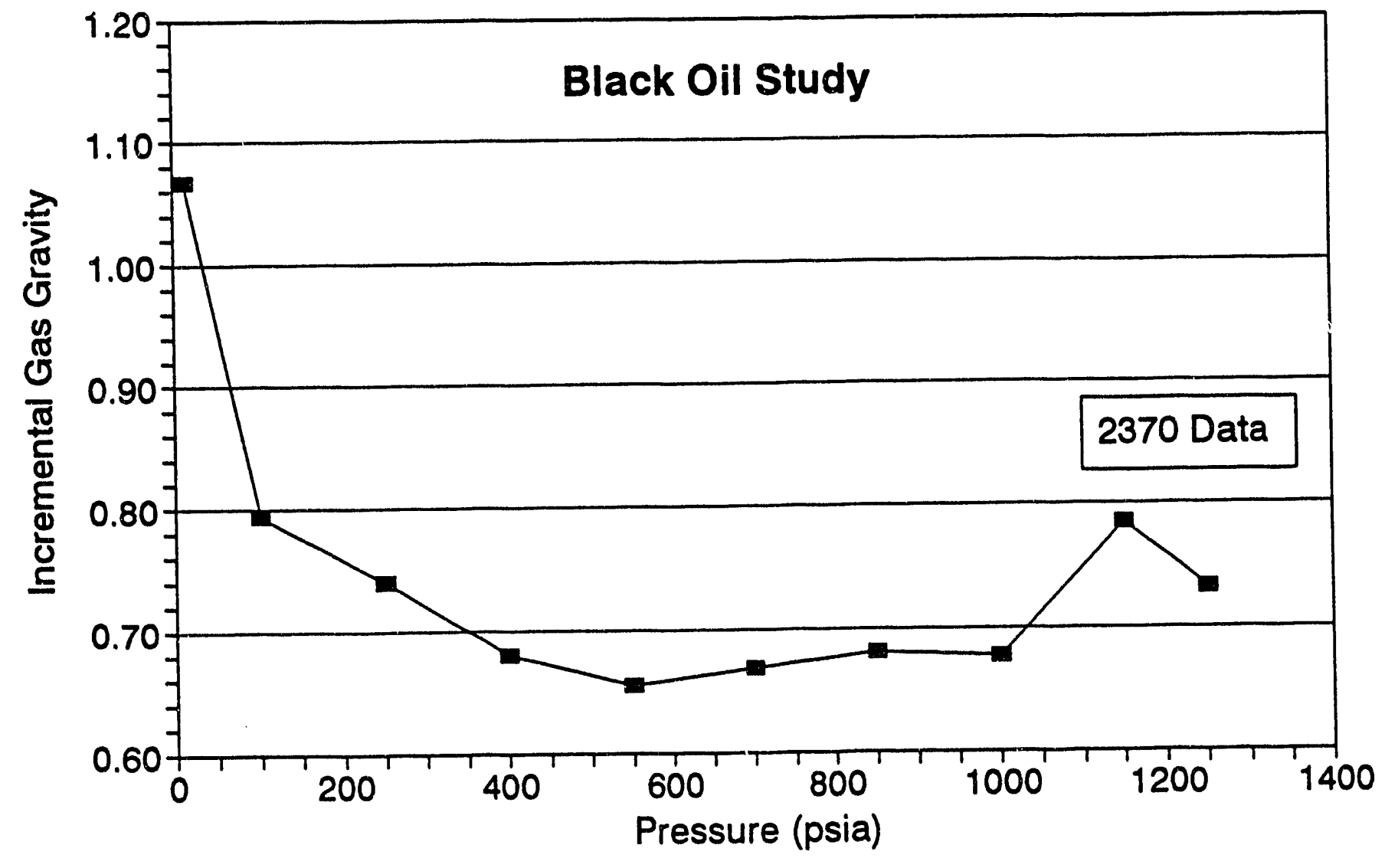

Figure 10. Liberated Gas Gravity. 


\section{Differential Vaporization}

Gas Formation Volume Factor

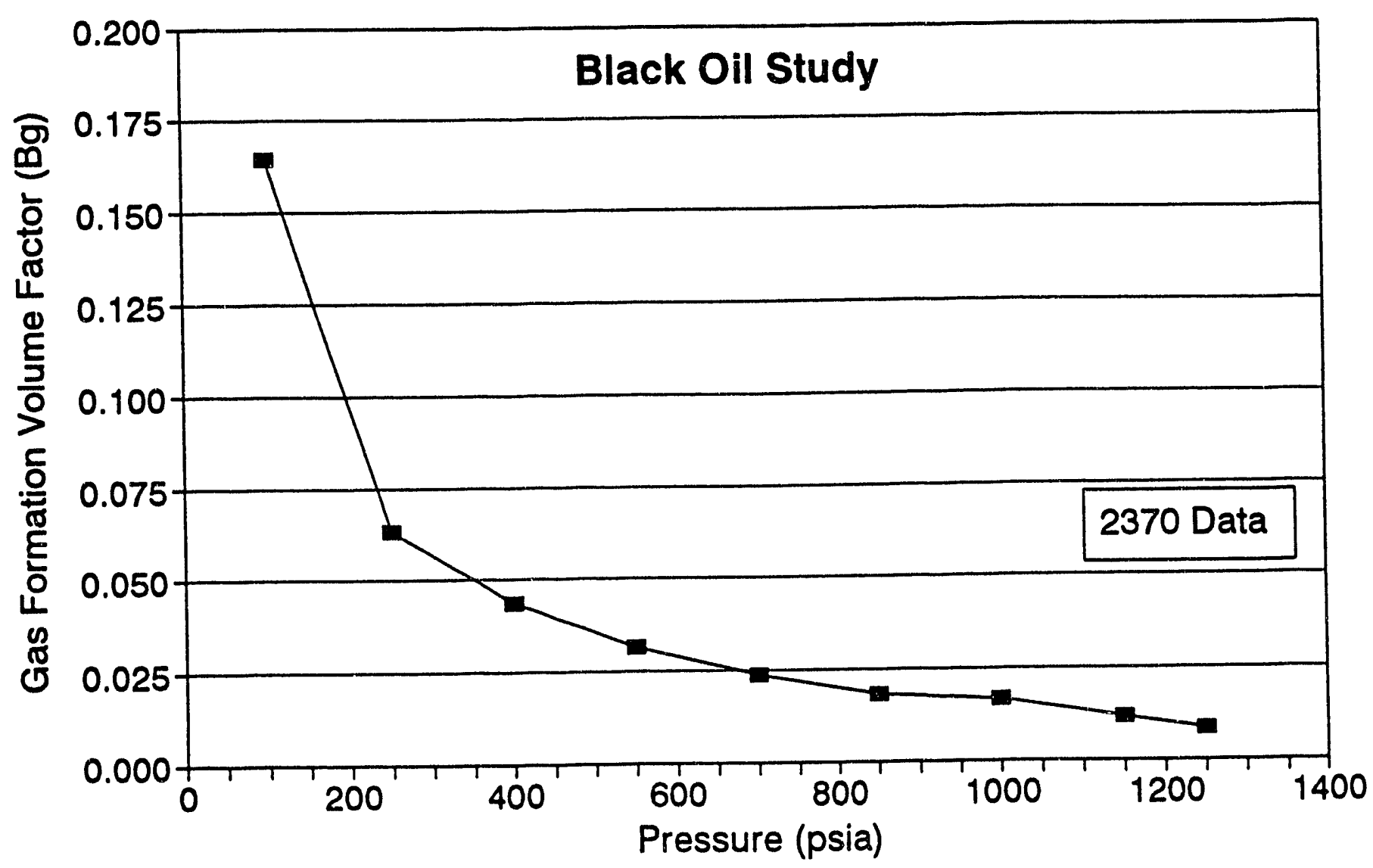

Figure 11. Differential Liberation Gas Formation Volume Factor. 


\section{Differential Vaporization}

Gas Deviation Factor

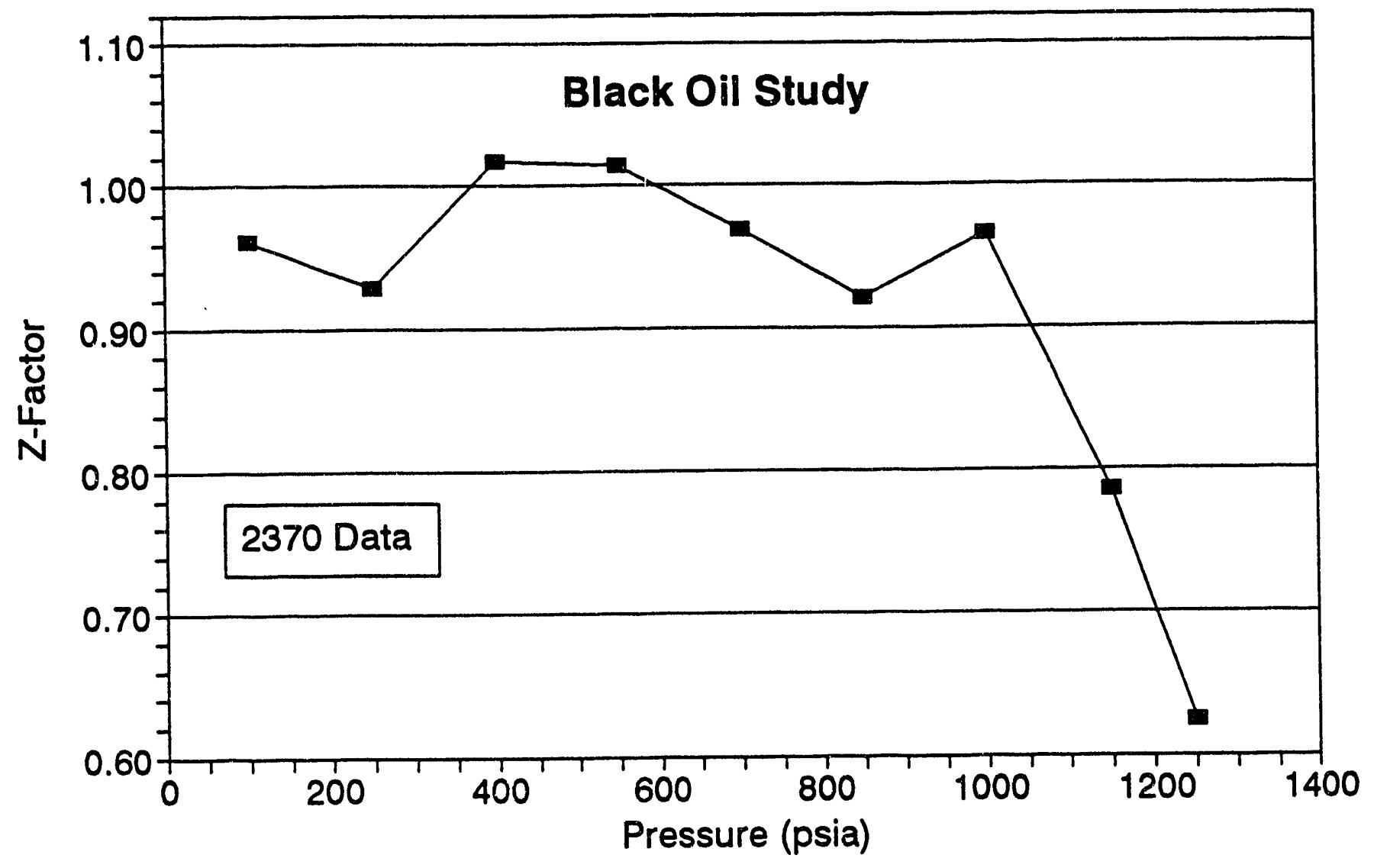

Figure 12. Gas Compressibility Factor. 
Table 9. Mole Fraction Distribution of Gas Mixture and Stock Tank Oil

\begin{tabular}{|c|c|c|}
\hline Component & Gas Mixture & Stock Tank Oil \\
\hline $\mathrm{CO}_{2}$ & 0.00795 & - \\
\hline $\mathrm{N}_{2}$ & 0.00561 & - \\
\hline $\mathrm{C}_{1}$ & 0.8218 & - \\
\hline $\mathrm{C}_{2}$ & 0.1086 & $\cdot$ \\
\hline $\mathrm{C}_{3}$ & 0.0435 & - \\
\hline $\mathrm{i}-\mathrm{C}_{4}$ & 0.00465 & - \\
\hline $\mathrm{n}-\mathrm{C}_{4}$ & 0.00789 & - \\
\hline $\mathrm{C}_{5}$ & - & 0.0587 \\
\hline $\mathrm{C}_{6}$ & - & 0.0909 \\
\hline $\mathrm{C}_{7}$ & - & 0.0933 \\
\hline $\mathrm{C}_{8}$ & - & 0.1030 \\
\hline $\mathrm{C}_{9}$ & - & 0.0849 \\
\hline $\mathrm{C}_{10}$ & - & 0.0704 \\
\hline $\mathrm{C}_{11}$ & - & 0.0560 \\
\hline $\mathrm{C}_{12}$ & - & 0.0445 \\
\hline $\mathrm{C}_{13}$ & - & 0.0328 \\
\hline $\mathrm{C}_{14}$ & - & 0.0405 \\
\hline $\mathrm{C}_{15+}$ & - & 0.3250 \\
\hline $\mathrm{TOTAL}_{\mathrm{L}}$ & 1.0000 & 1.0000 \\
\hline & & \\
\hline & & - \\
\hline
\end{tabular}

Table 10. Physical Properties of the Stock Tank Oil and Gas Mixture

Properties of the Gas Mixture

Molecular weight

Density, g/cc@60 F, 14.7 psia

Density,g/cc@80 $\mathrm{F}, 1800$ psia

Properties of Stock Tank Oil

Molecular weight of STO

Density of STO@60 $\mathrm{F}, \mathrm{g} / \mathrm{cc}$

API gravity of STO@60 $\mathrm{F}$

Recombined gas/oil ratio
19.6

0.0008302

0.1333

221

0.8689

31.4

250 scf/bbl STO@60F 
Table 11. Summary of PVT Data

\begin{tabular}{||l|l|}
\hline \multicolumn{2}{||c|}{ Conditions of the Experiment } \\
\hline Run Temperature: & $145^{\circ} \mathrm{F}$ \\
\hline Working Pressure: & 5000 psia \\
\hline Base Temperature: & $60^{\circ} \mathrm{F}$ \\
\hline Base Pressure: & 14.696 psia \\
\hline
\end{tabular}

\begin{tabular}{||l|l|}
\hline \multicolumn{2}{|c|}{ Pressure-Volume Relations } \\
\hline Saturation Pressure & $1352 \pm 20 \mathrm{psia}^{2}$ \\
\hline Avg Single-Phase Compressibility & $10.4 \times 10^{-6} \mathrm{v} / \mathrm{v} / \mathrm{psi}(5000-1352 \mathrm{psia})$ \\
\hline Thermal Exp @ 5000 psia & $1.0243 \mathrm{~V} @ 145^{\circ} \mathrm{F} / \mathrm{V} @ 85.0^{\circ} \mathrm{F}$ \\
\hline
\end{tabular}

\begin{tabular}{|l|l|}
\hline \multicolumn{2}{|c|}{$\begin{array}{c}\text { Differential Vaporization Data } \\
\text { (at } 1352 \text { psia and } 145^{\circ} \mathrm{F} \text { ) }\end{array}$} \\
\hline Solution Gas/Oil Ratio & $254 \mathrm{scf} / \mathrm{bbl}$ residual oil @ $60^{\circ} \mathrm{F}$ \\
\hline Relative Oil Volume & $1.1325 \mathrm{bbl} / \mathrm{bbl}$ residual oil @ 60 $\mathrm{F}$ \\
\hline Density of Reservoir Fluid & $\mathrm{n} / \mathrm{a}$ \\
\hline
\end{tabular}

2 Based on the accuracies of pressure, teniperature, and volume measurements. 
Table 12. Average Single-Phase Compressibilities

\begin{tabular}{|c|c|}
\hline $\begin{array}{c}\text { Pressure Range } \\
\text { (psia) }\end{array}$ & $\begin{array}{c}\text { Single-Phase Compressibility } \\
\text { v/v/psi }\end{array}$ \\
\hline 5000 to 4000 & $8.42 \times 10^{-6}$ \\
\hline 4000 to 3000 & $9.26 \times 10^{-6}$ \\
\hline 3000 to 2000 & $10.78 \times 10^{-6}$ \\
\hline 2000 to 1352 & $15.23 \times 10^{-6}$ \\
\hline
\end{tabular}


Table 13. Pressure-Volume Relations for the Black Oil Mixture at $145^{\circ} \mathrm{F}$

\begin{tabular}{|c|c|c|c|}
\hline $\begin{array}{c}\mathrm{P} \\
\text { (psia) }\end{array}$ & $\begin{array}{c}\mathrm{V} \\
(\mathrm{cc})\end{array}$ & $\begin{array}{l}\text { Relative } \\
\text { Volume } \\
\end{array}$ & $\begin{array}{c}\mathrm{Y} \\
\text { Function } \\
\end{array}$ \\
\hline 5000 & 96.50 & 0.9622 & \\
\hline 4500 & 96.90 & 0.9662 & \\
\hline 4000 & 97.32 & 0.9704 & \\
\hline 3500 & 97.76 & 0.9748 & \\
\hline 3000 & 98.23 & 0.9795 & \\
\hline 2500 & 98.73 & 0.9844 & \\
\hline 2000 & 99.30 & 0.9901 & \\
\hline 1800 & 99.55 & 0.9926 & \\
\hline 1600 & 99.83 & 0.9954 & \\
\hline 1500 & 99.97 & 0.9968 & \\
\hline 1450 & 100.05 & 0.9976 & \\
\hline 1400 & 100.13 & 0.9984 & \\
\hline 1375 & 100.17 & 0.9988 & \\
\hline 1352 & 100.29 & 1.0000 & \\
\hline 1350 & 100.32 & 1.0003 & \\
\hline 1300 & 101.58 & 1.0129 & 3.110 \\
\hline 1250 & 102.96 & 1.0266 & 3.065 \\
\hline 1200 & 104.51 & 1.0421 & 3.010 \\
\hline 1100 & 108.15 & 1.0784 & 2.923 \\
\hline 1000 & 112.77 & 1.1244 & 2.829 \\
\hline 881 & 119.94 & 1.1959 & 2.729 \\
\hline 671 & 140.07 & 1.3966 & 2.559 \\
\hline 505 & 170.18 & 1.6969 & 2.407 \\
\hline 385 & 210.00 & 2.0939 & 2.296 \\
\hline 300 & 260.00 & 2.5925 & 2.202 \\
\hline 246 & 310.00 & 3.0910 & 2.150 \\
\hline 207 & 360.60 & 3.5956 & 2.131 \\
\hline
\end{tabular}

Relative Volume: Total Volume at indicated $T$ and $P$ per volume at saturation pressure. 
Table 14. Differential Vaporization Data for the Black Oil Mixture at $145^{\circ} \mathrm{F}$

\begin{tabular}{|c|c|c|c|c|c|c|c|}
\hline $\begin{array}{c}\text { Pressure } \\
\text { (psia) }\end{array}$ & $\begin{array}{c}\text { Solution } \\
\text { Gas/Oil } \\
\text { Ratio } \\
\mathrm{R}_{\text {sd }} \\
\end{array}$ & $\begin{array}{c}\text { Relative } \\
\text { Oil } \\
\text { Volume } \\
\mathrm{B}_{\text {od }} \\
\end{array}$ & $\begin{array}{c}\text { Relative } \\
\text { Total } \\
\text { Volume } \\
B_{\text {td }} \\
\end{array}$ & $\begin{array}{c}\text { Oil } \\
\text { Density } \\
\text { (g/cc) } \\
\end{array}$ & $\begin{array}{c}\text { Gas } \\
\text { Deviation } \\
\text { Factor } \\
\mathrm{Z} \\
\end{array}$ & $\begin{array}{c}\text { Gas } \\
\text { Formation } \\
\text { Volume } \\
\text { Factor, } B_{g}\end{array}$ & $\begin{array}{c}\text { Inc. Gas } \\
\text { Gravity } \\
(\mathrm{Air}=1.0)\end{array}$ \\
\hline 1352 & 254 & 1.133 & 1.133 & & & & \\
\hline 1250 & 235 & 1.127 & 1.156 & & 0.624 & 0.00854 & 0.733 \\
\hline 1150 & 217 & 1.213 & 1.159 & & 0.787 & 0.01169 & 0.786 \\
\hline$\because n 0$ & 194 & 1.115 & 1.183 & & 0.966 & 0.01652 & 0.678 \\
\hline 850 & 168 & 1.106 & 1.192 & & 0.921 & 0.01852 & 0.681 \\
\hline 700 & 145 & 1.097 & 1.197 & & 0.969 & 0.02368 & 0.668 \\
\hline 550 & 121 & 1.088 & 1.220 & & 1.015 & 0.03154 & 0.655 \\
\hline 400 & 97 & 1.080 & 1.267 & & 1.017 & 0.04348 & 0.679 \\
\hline 250 & 70 & 1.071 & 1.382 & & 0.928 & 0.06348 & 0.740 \\
\hline 100 & 41 & 1.061 & 1.903 & & 0.962 & 0.16448 & 0.794 \\
\hline \multirow[t]{2}{*}{14.7} & 0 & 1.034 & & & & & 1.067 \\
\hline & (a) $60^{\circ} \mathrm{F}=$ & 1.000 & & & & & \\
\hline
\end{tabular}

Gravity of Residual Oil = 30.1 ${ }^{\circ} \mathrm{API} @ 60^{\circ} \mathrm{F}$

Density of Residual Oil=0.87\% sc: @ 60 $\mathrm{F}$

$\mathbf{R}_{\mathrm{sd}}=$ Cubic feet of gas @ $14.696 \mathrm{psia} \& 60^{\circ} \mathrm{F}$ per barr . of residual oil @ $60^{\circ} \mathrm{F}$

$\mathrm{B}_{\text {od }}=$ Barrel of oil @ T \& P per barrel of residual oil @ $60^{\circ} \mathrm{F}$

$B_{\text {td }}=$ Barrel of oil plus free gas @ T \& P per barre! 、 $i$ residual oil @ $60^{\circ} \mathrm{F}$

$\mathrm{B}_{\mathrm{g}}=$ Cubic feet of gas @ T \& $\mathrm{P}$ per cubic feet 14.696 psia and $60^{\circ} \mathrm{F}$ 
To perform the comparative studies with conventional equipment, parallel tests were conducted on a mercury-based instrument. The ingredients used to synthesize the oil along with the gas/oil ratio and recimbination conditions were sent to a commercial PVT laboratory. Constant composition and differential liberation tests were performed on the recombined oil using a through-windowed mercury PVT cell at $145^{\circ} \mathrm{F}$.

Figure 13 shows a comparison of the 2370 and $\mathrm{Hg}$-based $\mathrm{PV}$ relation data. Table 15 summarizes the comparison of the results based on a number of measured properties. The second column is the data obtained with the 2370 system while the third column shows the same property measured with a mercury-based apparatus.

Table 15. Comparison of 2370 and Mercury-Based Results for a Black Oil System

\begin{tabular}{|l|c|c|}
\hline \multicolumn{1}{|c|}{ Measured Property } & 2370 Data & Mercury-Based Data \\
\hline $\begin{array}{l}\text { Thermal Expansion Coefficient } \\
\left(\mathrm{cm}^{3} / 0 \mathrm{~F}\right)\end{array}$ & 0.0426 & 0.0427 \\
\hline Saturation Pressure (psia) & 1352 & 1455 \\
\hline Liberated Gas (scf/bbl res. oil) & 254 & 257 \\
\hline $\begin{array}{l}\text { Avg. Single-Phase } \\
\text { Compressibility (v/v/psi) }\end{array}$ & $10.4 \times 10^{-6}$ & $6.78 \times 10^{-6}$ \\
\hline $\begin{array}{l}\text { Relative Oil Volume } \\
\text { (bbl/bbl res. oil) }\end{array}$ & 1.133 & 1.149 \\
\hline \begin{tabular}{l} 
Residual Oil Gravity ( ${ }^{\circ}$ API) \\
\hline
\end{tabular} & 30.1 & 30.6 \\
\hline
\end{tabular}

A casual glance at the results show that non-trivial differences exist between the two sets of data. One, however, must be careful in making conclusions and interpretations based on these results for a number of reasons. The data obtained from PVT studies can be strongly technique dependent. Two operators performing the same experiment under identical conditions can get slightly different results. Further, no error bars or measurement accuracies were provided with the mercury-based results. It is therefore misleading to assume that the latter is the standard for comparison. At any rate, the study is not altogether meaningless. On a general level, it proves that the 2370 PVT system is capable of performing routine reservoir fluid analyses. Conclusions regarding relative accuracies will have to be deferred until a more controlled and thorough study is performed.

Note that the 2370 -measured saturation pressure is about 100 psi lower than the mercury-based result. This could be partly due to the lower solution gas/oil ratio as determined by the 


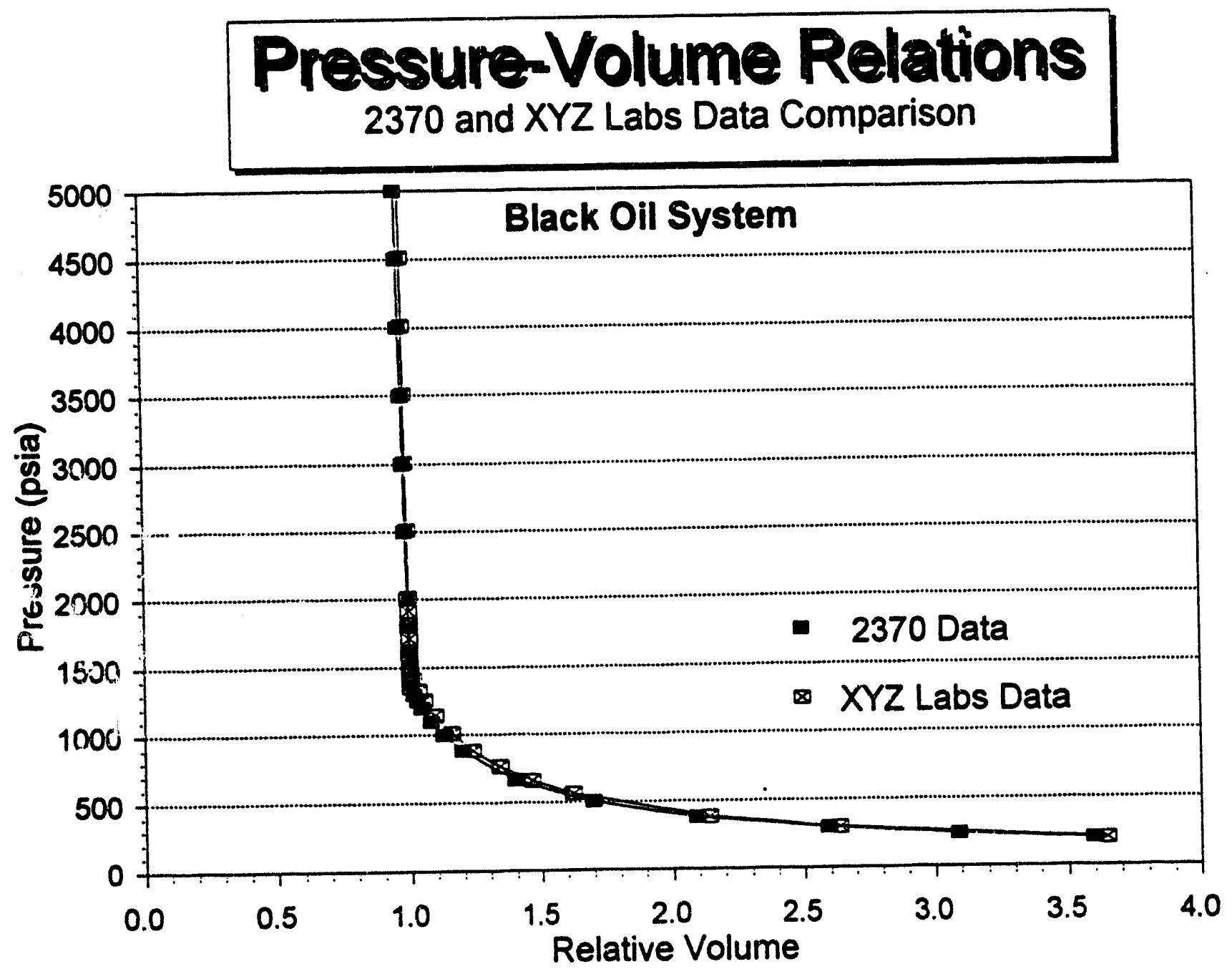

Figure 13. Comparison of 2370 and Mercury-Based Data on a Black Oil System. 
differential liberation test. A difference that stands out, however, is the discrepancy of the average single-phase compressibilities. Although a very small number (order of $10^{-6}$ ), the average compressibility calculated from the 2370 data (from 5000 psia to the saturation pressure) is about $53 \%$ larger compared to the mercury-based result. It is not inconceivable that subtle differences in composition of the two mixtures as a result of the recombination could have an effect on the compressibility of the single-phase fluid. It is suspected, however, that the large discrepancy (percentage wise) could be partly due to the additional compressibility provided by the seals in the system. This effect would be particularly pronounced at elevated pressures where the volume of the mixture would be smaller at the same pressure compared to a system without the additional seal compressibility.

The seal compressibility is not currently accounted for in the volume calculation algorithm. Tests are scheduled to characterize this phenomenon and a correction term will be included in the volume calculation routine if the seal compression is found to be non-negligible.

\section{Gas Condensate Testing}

Experiments were also conducted on a gas condensate system to test the ability of the 2370 to determine a dew point saturation pressure. A retrograde condensate mixture was synthesized from a $60^{\circ} \mathrm{API}$ gravity stock tank oil, hexanes, and an 80/10/10 mole percent methane, ethane, and propane gas mixture.

The STO was diluted with hexanes to $50 / 50 \%$ by volume ratio. The diluted STO and the gas were then recombined to a gas/oil ratio of 6000 standard cubic feet per barrel of STO at $60^{\circ} \mathrm{F}$. The mixture was prepared and stored in a floating piston cylinder and maintained at 8000 psia and ambient temperature.

Approximately $180 \mathrm{cc}$ 's of the recombined fluid was transferred into the PC and FPC simultaneously and thermally expanded to $150^{\circ} \mathrm{F}$. A constant composition expansion test was performed on the mixture together with liquid dropout measurement in the two-phase region. The dew-point pressure was determined to be 6750 psia at the $150^{\circ} \mathrm{F}$. A maximum liquid dropout of $42 \%$ (liquid volume at pressure per unit volume at saturation expressed as percent) was established at 2000 psia. A summary results are presented in Table 16 and the PV and liquid dropout curves are shown in Fig. 14.

Note that PV curve is characterized by smooth first and second derivatives which is typical of condensate fluids. This is due to the gradual change of compressibility from a homogeneous single-phase fluid to a two-phase mixture. The liquid dropout curve shows the retrograde condensation phenomenon which is characterized by a slow increase in liquid volume at pressures below but close to the dew-point pressure. At pressures sufficiently away from the saturation value, the condensation rate increases rapidly until the liquid volume reaches a maximum before re-vaporization begins as the pressure is further decreased. 
Table 16. Pressure-Volume Relation and Liquid Dropout Data for the Gas Condensate Mixture at $150^{\circ} \mathrm{F}$.

\begin{tabular}{|c|c|c|c|}
\hline$\underset{\text { (psia) }}{P}$ & $\begin{array}{l}\text { Relative } \\
\text { Volume }\end{array}$ & $\begin{array}{l}\text { Liquid Vol. } \\
\text { Percent }\end{array}$ & Y-Function \\
\hline 8000 & 0.966 & & \\
\hline 7759 & 0.972 & & \\
\hline 7500 & 0.978 & & \\
\hline 7250 & 0.986 & & \\
\hline 7000 & 0.994 & & \\
\hline 6750 & 1.000 & 0.00 & $<$ DP \\
\hline 5573 & 1.041 & 2.55 & 5.145 \\
\hline 5008 & 1.063 & 7.91 & 5.492 \\
\hline 4529 & 1.093 & 14.10 & 5.297 \\
\hline 4000 & 1.136 & 21.85 & 5.061 \\
\hline 3500 & 1.199 & 29.73 & 4.674 \\
\hline 3000 & 1.302 & 36.68 & 4.140 \\
\hline 2500 & 1.490 & 41.32 & 3.472 \\
\hline 1997 & 1.831 & 42.08 & 2.864 \\
\hline 1500 & 2.470 & 40.29 & 2.380 \\
\hline
\end{tabular}

Relative Volume: V/Vsat or volume at indicated pressure divided by volume at saturation pressure. Liquid Volume Percent: Percent of saturated volume. 


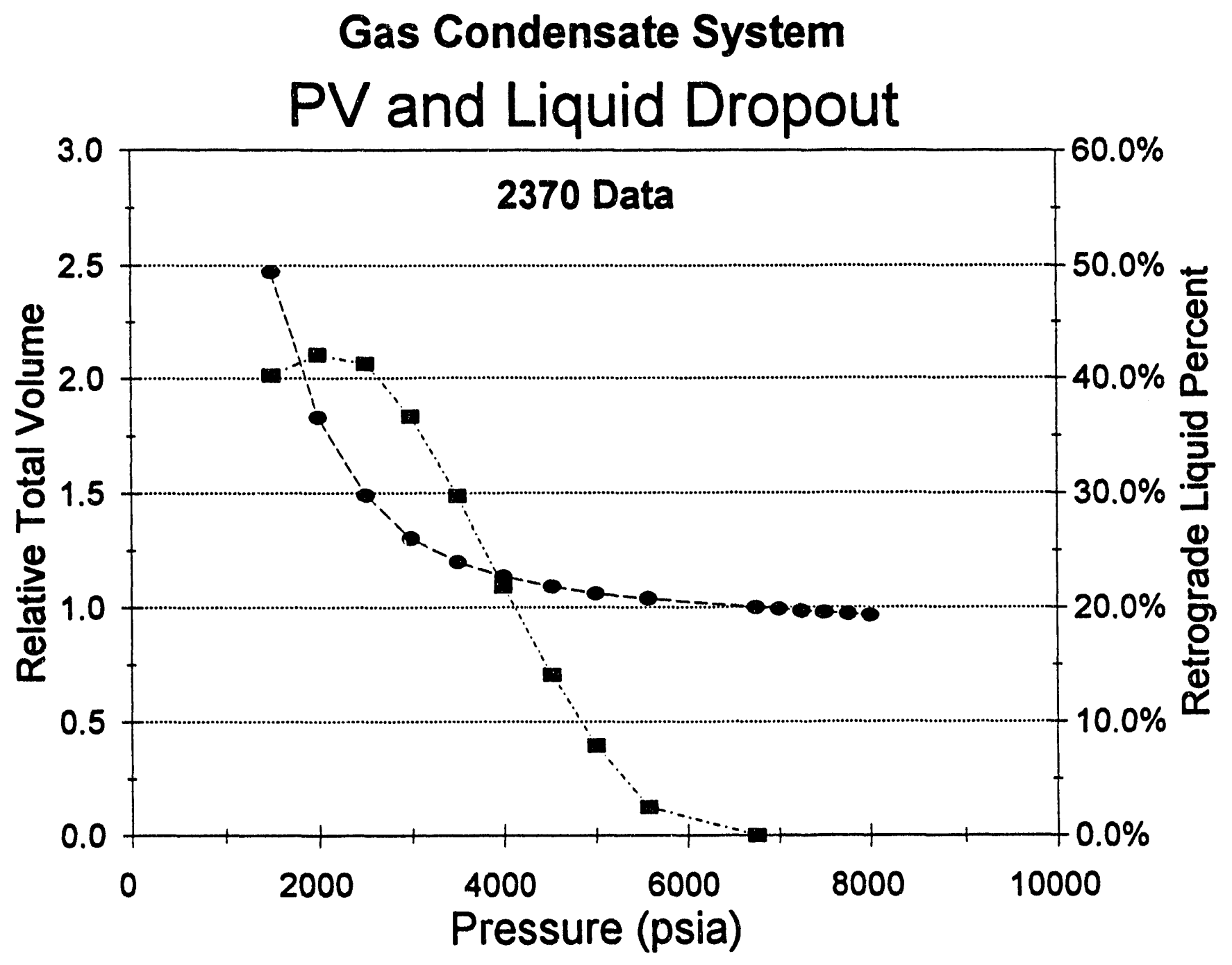

Figure 14. Relative Total Volume and Liquid Dropout Curves for the Gas Condensate System. 
Parallel tests were performed by a commercial PVT laboratory in a three-windowed mercury condensate cell to provide data for comparison purposes. The sample used in the mercury-based study came from the same recombination batch to avoid any questions with regards to differences in composition.

Figure 15 shows a comparison of the 2370 and mercury-based PV relation and liquid dropout data. Table 17 summarizes the comparison based on some characteristic properties.

Table 17. Comparison of 2370 and $\mathrm{Hg}$-Based Results for a Gas Condensate System

\begin{tabular}{|l|c|c|}
\hline \multicolumn{1}{|c|}{ Measured Property } & 2370 Data & Mercury-Based Data \\
\hline Saturation Pressure (psia) & 6750 & 6835 \\
\hline $\begin{array}{l}\text { Maximum Liquid Dropout } \\
\text { (\% of sat. vol.) }\end{array}$ & $42 \%$ at 2000 psia & $45 \%$ at 2000 psia \\
\hline
\end{tabular}

As with the black oil comparison study, the same degree of caution would have to be applied in interpreting the data. The comparative tests performed here should be viewed as a preliminary study from which soft conclusions can be drawn. The susceptibility of the studies performed here on the techniques and procedures used perhaps, would make it difficult to draw hard conclusions even in a controlled environment. Thus, the deviations between the data sets can only be viewed in a relative manner in the absence of a true reference standard.

The data generated by the 2370 apparatus, in itself, shows internal consistency and behavior that are characteristic of the type of fluid studied. The dew-point pressure was established visually by the occurrence of "clouding" upon pressure drawdown starting from a clear homogeneous single-phase fluid. The measurements were repeated over a range in expansion rates to determine the effect of adiabatic cooling during the expansion. Temperatures recorded during the experiment show that a $0.2-0.4^{\circ} \mathrm{F}$ temperature drop occurs 5-8 minutes after the expansion. Slight differences were observed using 20,10 , and $5 \mathrm{cc} / \mathrm{min}$ expansion rates starting at $8000 \mathrm{psia}$. The value observed at $10 \mathrm{cc} / \mathrm{min}$ were repeatable to within $\pm 3 \mathrm{psi}$ and is the number reported.

Traditionally, the effect of adiabatic cooling on the reported dew-point pressure has largely been neglected. Part of the reason could be the pronounced change in the fluid as it traverses the phase envelope during rapid expansion. Very lean condensates, for instance, exhibit very subtle change even at pressures well below the dew point. This makes it difficult to perform visual dew point determinations even with a trained pair of eyes. The rapid expansion yields an unmistakable change which makes it easier for the operator to make a visual call of the dew-point pressure. Unfortunately, what facilitates the measurement introduces error in the measured value. The amount of bias this procedure has introduced in the existing data base is largely unquantified. 


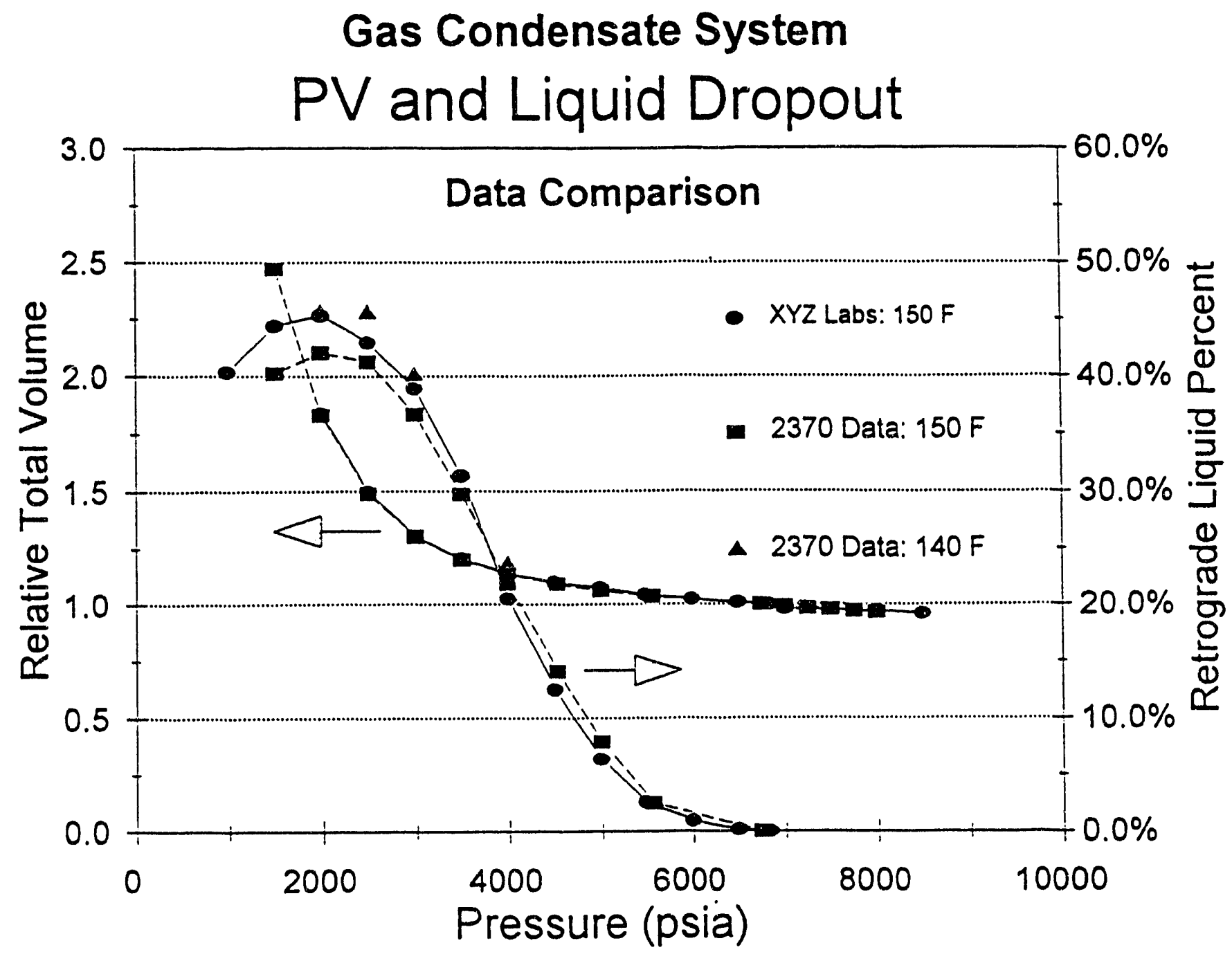

Figure 15. Comparison of 2370 and $\mathrm{Hg}$-Based Data on a Retrograde Condensate System. 
What is needed perhaps is a method of determining the onset of phase change without relying on a visual technique. Certain properties that exhibit a sharp discontinuity at the phase boundary can be monitored and correlated to a phase change. This technique would eliminate the subjectivity associated with the visual method.

A careful examination of the data suggests that the discrepancies between the 2370 and the mercury-based results can be explained by temperature deviations. The data would be consistent if one assumes that the test performed on the latter was at a slightly lower temperature. A lower temperature would explain the slightly higher dew-point pressure and the higher peak in the retrograde liquid curve. The vertical line drawn on a P-T diagram in the retrograde region would be a vertical tangent to a higher iso-volume curve at lower temperature resulting in a higher liquid dropout peak.

An additional test was performed on the condensate mixture at $140^{\circ} \mathrm{F}$ on the 2370 . The liquid dropout data points are shown in Fig. 15 as solid triangles. Note that the 2370 data at 140 and $150^{\circ} \mathrm{F}$ brackets the results obtained from the mercury-based test. The dropout curves appears to peak at around $46 \%$ at 2500 psia. One could make a strong case for the temperature-deviation arguement based on this result. A $3-5^{\circ}$ difference between the 2370 and mercury-based apparatus is not altogether impossible and would seem to account for the observed deviation.

\section{PROJECT PROSPECTS}

The current capabilities of the 2370 instrument together with its auxiliary apparatus is sufficient for typical reservoir fluid analysis. There are instances, however, when more information is required on the fluid being studied than the traditional PVT analysis provides. These properties include equilibrium phase compositions, phase viscosities and densities, and surface tension. These type of measurements can be of interest with university-based research laboratories or government and semi-private research institutions.

Ruska has a "wish list" of future projects for the 2370 mercury-free PVT system. These include: (1) a sampling loop that would allow the connection to a gas chromatograph for composition analysis; (2) an on-line densitometer for phase density measurements; (3) an on-line quartz crystal viscometer for phase viscosity measurements; (4) attachment and plumbing for a commercial surface tensiometer; and (5) an automated interface tracking system for relative phase volume measurements and phase change detection.

Providing these additional features will greatly enhance the capabilities of a PVT laboratory to better characterize reservoir fluids in terms of its physical and thermodynamic properties. Although it is difficult to quantify the direct effect oil exploration and recovery efficiency, it is obvious that an extensive data base of reservoir fluid properties will have a positive impact on the energy industry. The availability of high speed computers has made numerical modeling and simulation a vital part of process design. The accuracy of model predictions can greatly benefit from extensive and accurate thermodynamic and physical properties of the process fluids. Thus, 
there is an incentive from a technical standpoint, at least, to develop a PVT apparatus that includes the above features.

\section{CONCLUDING REMARKS}

The work presented in this report is summarized in the following conclusions:

1. The 2370 Mercury-Free PVT system has undergone substantial improvements and enhancements from its prototype version that makes for a robust measurement system. These improvements include:

a. A selection of seal materials that covers the temperature and fluid compatibility range for applications in the petroleum and, to a large extent, the petrochemical industries

b. A bleed port that facilitates sample drainage and cleaning procedures which reduces the down-time between experiments

c. An improved oven and air circulation to ensure fluid temperature homogeneity.

2. The pressure reading accuracy, based on the results of the density measurements on propane, is estimated to be better than $\pm 0.15 \%$ of full scale reading ( \pm 15 psia).

3. The temperature reading accuracy, based on the results of the density measurements on propane, is estimated to be within $\pm 0.5^{\circ} \mathrm{F}$.

4. Preliminary test results suggest that the volume measurement accuracy is probably around $\pm 0.1 \mathrm{~cm}^{3}$.

5. The Ruska 2370 Mercury-Free PVT System is an apparatus that can be used to perform fluid phase behavior studies and reservoir fluid analyses. The routine studies performed on crude oils such as constant composition expansion and differential vaporization tests can be accomplished as well, if not better, than a mercury-based PVT apparatus. 


\section{REFERENCES}

1. 1986 Annual Book of ASTM Standards, Vol $01.05,615$.

2. Vargaftik, N.B.: Handbook of Physical Properties of Liquids and Gases, 2nd ed., Hemisphere Publishing Corp., New York (1975).

3. Ely, J.F. and Huber, M.L.: "NIST Thermophysical Properties of Hydrocarbon Mixtures Database," Version 1.0, National Institute of Standards and Technology, Standard Reference Data Program (1990). 

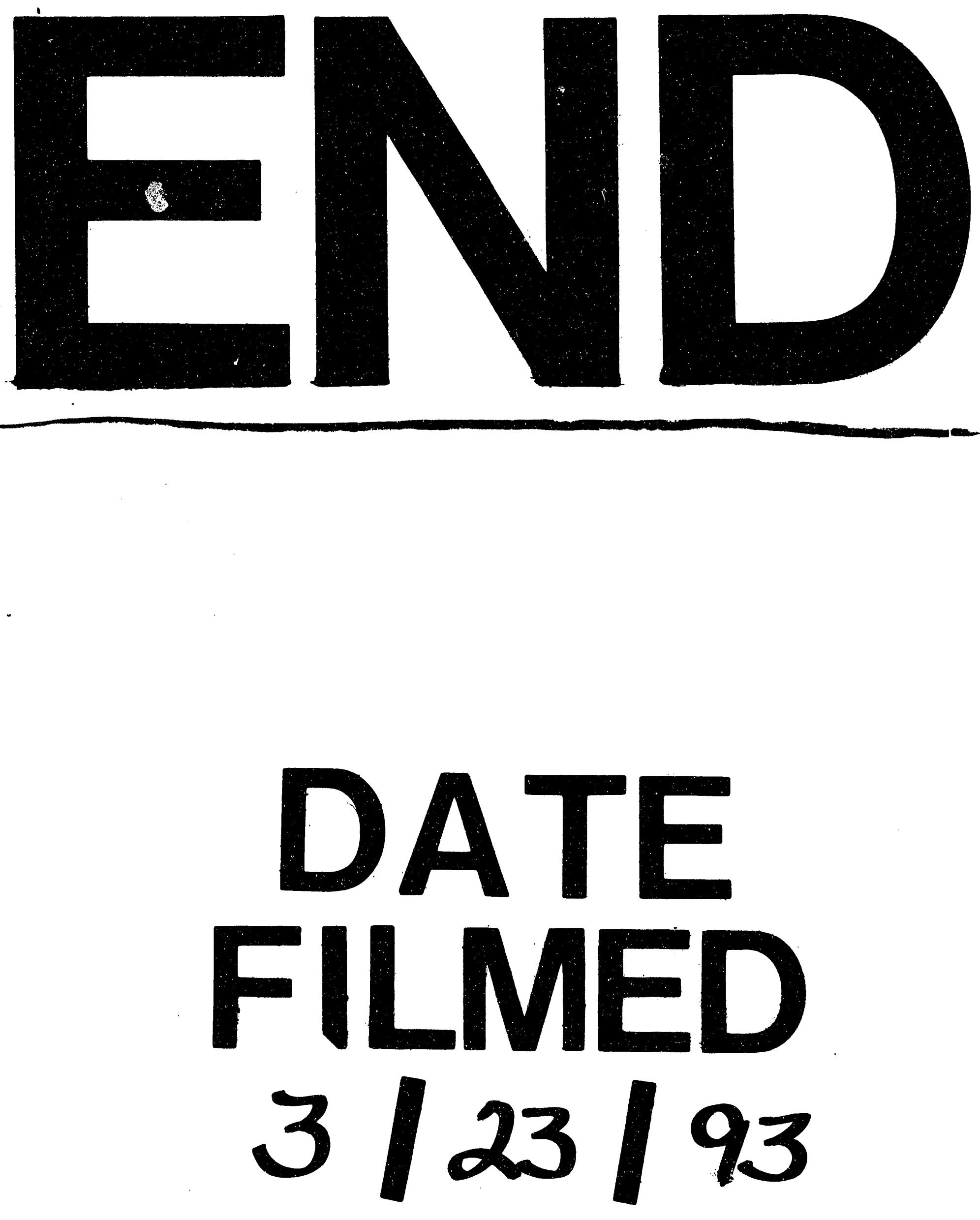

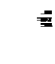


